\title{
Private INVESTMENT Fund REgulation - THEORY AND EMPIRICAL EVIDENCE FROM 1998 TO 2016
}

\author{
Wulf A. Kaal*
}

ABSTRACT

Private investment fund regulation in the United States evolved substantially in the last two decades. Tracing the main regulatory developments, this Article summarizes the author's theoretical and empirical findings on the effects of changes in private investment fund regulation from 2006 to 2016, assessing the regulatory implications of the failure of LongTerm Capital Management L.P. in 1998 and the Dodd-Frank Act in 2010. More recent trends include the emerging confluence of private investment funds and mutual funds as well as private investment funds' use of blockchain technology and smart contracts.

Key Words: Private Investment Funds, Hedge Funds, Private Equity, Long Term Capital Management, Regulation, Dodd-Frank Act, PFIARA, Compliance, Blockchain, Distributed Ledger Technology, Artificial Intelligence, Machine Learning, Data Science, Data Scientists, Meta Models, Innovation, Entrepreneur, Startup, Big Data, Diversification, Optimization, Efficiency

JEL Categories: K20, K23, K32, L43, L5, O31, O32

* (C) 2017 Wulf A. Kaal. Associate Professor, University of Saint Thomas School of Law and Director of the Private Investment Funds Institute, Minneapolis. The author sincerely thanks the many industry representatives who provided comments and feedback on initial drafts of this article. He is also grateful for outstanding research assistance from librarian Ann Bateson. 
INTRODUCTION

I. INITIAL REGULATORY FRAMEWORK IN THE UNITED STATES....583

A. Reliance on Exemptions

B. Evolution of the Investment Advisers Act Exemption ...585

II. FAILURE OF LONG-TERM-CAPITAL MANAGEMENT

A. Critique of Regulatory Proposals ..................................588

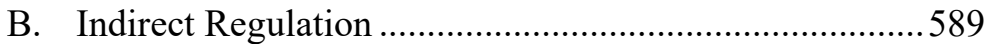

III. DODD-FRANK-ACT...........................................................591

A. Implications of Title IV-Empirical Evidence................593

B. Systemic Risk .............................................................608

C. Private Fund Investor Due Diligence .............................611

IV. CONFLUENCE OF PRIVATE AND MUTUAL FundS ....................613

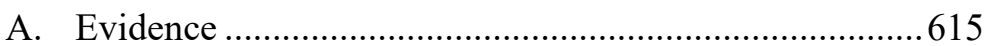

B. Implications …...........................................................616

V. BLOCKCHAIN TECHNOLOGY APPLICATIONS FOR PRIVATE

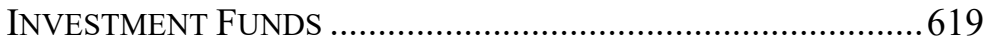

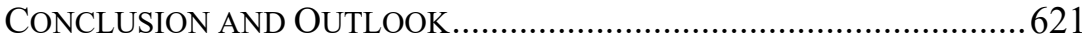

\section{INTRODUCTION}

Private investment fund regulation in the United States and the corresponding scholarship evolved as the private investment fund industry advanced from a niche market participant in the early 1950s to a major industry operating in international financial markets today. The available scholarship traces the main developments in private investment fund regulation in three major phases beginning in 1998. The post 1998 phases in regulatory developments of private investment funds are distinguishable from the incremental changes in the applicable SEC rulemaking and regulatory developments from the 1950s to 1998 because of the heightened intensity of regulatory supervision post 1998.

In phase one, domestic and international regulatory bodies examined ways to improve the existing regulatory framework pertaining to private investment funds in the aftermath of the 1998 failure of Long-Term Capital Management, L.P. ("LTCM"), the largest hedge fund failure to date. ${ }^{1}$ Phase

1. See Wulf A. Kaal, Hedge Fund Regulation by Banking Supervision: A COMPARATIVE InSTITUTIONAL ANALYsis, 58-72, 133-71 (European Univ. Studies, Ser. V., Econ. \& Mgmt., Vol. 3174 2006) [hereinafter Kaal, BANKING SUPERVISION] (summarizing the legislative and regulatory measures in response to LTCM in the United Kingdom, France, and the United States and evaluating the proposals for improvements of the then existing regulatory framework for private investment funds through various domestic and international regulatory bodies and industry groups). 
two, starting in 2010 with the passage of the Dodd-Frank Act ${ }^{2}$ ("Title IV" or "Dodd-Frank"), is dominated by the increasing regulatory scrutiny of the private investment fund industry under the Dodd-Frank Act and the associated rules and Securities and Exchange Commission ("SEC") guidance. The SEC continues to refine and expand the regulatory landscape for the private fund industry in the aftermath of the Dodd-Frank Act and the Jumpstart Our Business Startups Act ("JOBS Act"), ${ }^{3}$ and it continues to amend rules and SEC reporting forms that apply to the private fund industry. ${ }^{4}$ Phase three is characterized by the emerging evidence of the confluence of prior separate asset classes ${ }^{5}$ in the aftermath of the Dodd-Frank Act and other long-term implications of the regulatory overhaul under the Dodd-Frank Act, such as the dilution of the public/private distinction in federal securities regulation.

This Article traces the main developments in each phase of private investment fund regulation from 1998 to 2016 and examines the author's core scholarly contributions and empirical findings pertaining to each phase. The author's scholarly contributions in phase one focused on evaluating the proposed remedies ${ }^{6}$ for private fund investment regulation and suggesting alternatives. ${ }^{7}$ Scholarship in phase two summarized the regulatory evolution

2. Dodd-Frank Wall Street Reform and Consumer Protection (Dodd-Frank) Act, Pub. L. No. 111-203, $\S \$ 401-416,124$ Stat. 1376, 1570-1580 (2010); id. at $\S 402$ (codified at 15 U.S.C. $\S 80 \mathrm{~b}-2$ (2012)) (regulating private investment funds following the financial crisis of 2008); id. at $\S 403$ (codified as amended at 15 U.S.C.A. $\S 80$ b-3) (West 2009 \& Supp. 2016).

3. Jumpstart Our Business Startups (JOBS) Act, Pub. L. No. 112-106, § 201(a)(1), 126 Stat. 306, 313-14 (2012).

4. See Wulf A. Kaal, The Post Dodd-Frank Act Evolution of the Private Fund Industry: Comparative Evidence from 2012 and 2015, 71 BUS. LAW. 1151, 1170-72 (2016) (manuscript), http://ssrn.com/abstract=2739479 [https://perma.cc/5EZX-VSX9] [hereinafter Kaal, Evolution] (outlining notable trends and regulatory developments in the private fund industry in the aftermath of Dodd-Frank).

5. See Wulf A. Kaal, Confluence of Private and Mutual Funds, in HANDBOOK ON MUTUAL Funds 1, 5 (manuscript), http://ssrn.com/abstract=2715083 [https://perma.cc/J9G6CDVK] [hereinafter Kaal, Confluence] (describing the effects of the proliferation of nontraditional asset classes).

6. See Kaal, BANKING SUPERVISION, supra note 1.

7. See, e.g., Wulf A. Kaal, Hedge Fund Regulation via Basel III, 44 VANDERBILT J. TrAnSNAT'L L. 389 (Apr. 9, 2011) (manuscript) (on file with the Social Science Research Network) [hereinafter Kaal, Basel III] (suggesting banking supervision via Basel III to remedy hedge funds' vast exposure to complex derivatives products and associated risks that were insufficiently addressed by the then existing regulatory framework); Wulf A. Kaal, Hedge Fund Valuation: Retailization, Regulation, and Investor Suitability, 28 REV. BANKING \& FIN. L. 581, 584 (2009) (manuscript), (on file with the Social Science Research Network) (exploring the issues created by valuation problems, and suggesting regulatory solutions); Kaal, BANKING SUPERVISION, supra note 1 (suggesting banking supervision as a promising indirect tool to improve lacking regulatory oversight of private funds). 
of the private fund industry ${ }^{8}$ and focused particularly on the evaluation of the effects of the Dodd-Frank Act on that industry. ${ }^{9}$ Scholarship in phase two also analyzed the shifting evaluation of the possible systemic risk posed by the private fund industry ${ }^{10}$ and pertinent developments in private investment fund investor due diligence. ${ }^{11}$ Scholarship in phase three evaluated the implications of the emerging evidence of the confluence of prior separate asset classes $^{12}$ in the aftermath of the Dodd-Frank Act and other long-term

8. See Wulf A. Kaal \& Dale A. Oesterle, The History of Hedge Fund Regulation in the United States, in HandbooK ON Hedge Funds, (Ohio State Public Law Working Paper No. 326 \& Univ. of St. Thomas (Minn.) Legal Stud. Res. Paper No. 16-05, 2016), https://papers.ssrn.com/sol3/papers.cfm?abstract_id=2714974 [https://perma.cc/2D8P-B9JP] (examining the history and evolution of private fund adviser regulation).

9. See generally Wulf A. Kaal, Hedge Fund Manager Registration Under the DoddFrank Act, 50 SAN DiEGO L. REV. 243, 245 (2013), http://ssrn.com/abstract=2150377 [https://perma.cc/2QZD-7NQY] [hereinafter Kaal, Registration] (explaining how regulation worked to counteract fraud corresponding to increased hedge fund access); Kaal, Evolution, supra note 4; Wulf A. Kaal, What Drives Dodd-Frank Act Compliance Costs for Private Funds? J. Alternative InV., 1, 8 (2016), http://ssrn.com/abstract=2629386 [https://perma.c c/HW3T-QS7W] [hereinafter Kaal, Compliance Costs] (evaluating which factors impact Dodd-Frank Act compliance costs); Wulf A. Kaal, The Effect of Private Fund Disclosures Under the Dodd-Frank Act, 9 BROOK. J. CORP., FIN. \& COM. L. 1, 9 (2015) (demonstrating that while the overall effect of private disclosures on the industry is moderate, there are still improvements to be made), http://ssrn.com/abstract=2447306 [https://perma.cc/HS86DCZD] [hereinafter Kaal, Private Fund Disclosures]; Wulf A. Kaal, Barbara Luppi, \& Sandra Paterlini, Did the Dodd-Frank Act Impact Private Fund Performance? - Evidence from 2010 2015 (July 10, 2015) (unpublished manuscript) http://ssrn.com/abstract=2629347 [https://perma.cc/TMM8-MWZE] (estimating the impact of private fund adviser registration and disclosure requirements under the Dodd-Frank Act on private fund performance); Wulf A. Kaal, Hedge Funds' Systemic Risk Disclosures in Bankruptcy, 22 AM. BANKR. INST. L. REV. 195, 197 (2014), http://ssrn.com/abstract=2348463 [https://perma.cc/48U7-MBQJ] [hereinafter Kaal, Bankruptcy] (analyzing the effect of disclosure requirements on hedge fund investors in bankruptcy proceedings).

10. See Kaal, Basel III, supra note 7; Wulf A. Kaal \& Timothy A. Krause, Hedge Funds and Systemic Risk, in HANDBOOK ON HEDGE FundS (manuscript), http://ssrn.com/abstract=2 748096 [https://perma.cc/43DK-U2KW] (explaining the shifting literature on hedge funds' systemic risk after Dodd-Frank); Wulf A. Kaal, The Systemic Risk of Private Funds After the Dodd-Frank Act, 4 Mich. Bus. \& ENTREPRENEURIAL L. ReV. 163, 169-70 (2015), http://ssrn.com/abstract=2470008 [https://perma.cc/YE58-UVDW] [hereinafter Kaal, Systemic Risk] (asserting that private funds create both a direct and indirect systemic risk); Kaal, Bankruptcy, supra note 9, at 199 (outlining SEC systemic risk disclosure requirements meant to eliminate risks posed by hedge funds).

11. See Wulf A. Kaal, Private Fund Investor Due Diligence-Evidence from 1995 to 2015, REV. BANKING \& FIN. L. 1, 6-7, http://ssrn.com/abstract=2811718 [https://perma.cc/NS T4-AUUE] [hereinafter Kaal, Due Diligence] (describing the increasing rigor of investor due diligence in response to the financial crisis of 2008-09 and other associated crises).

12. See Kaal, Confluence, supra note 5; Wulf A. Kaal \& Bentley J. Anderson, Uncons trained Mutual Funds and Retail Investor Protection, REV. BANKING \& FIN. L. (manuscript), http://ssrn.com/abstract=2811729 [https://perma.cc/TV7N-AZ5T] [hereinafter Kaal \& Anderson, Protection] (exploring the protection necessary to address issues from the growth 
implications of the regulatory overhaul under the Dodd-Frank-Act, such as the dilution of the public/private distinction in federal securities regulation. ${ }^{13}$

This Article has four main parts. After an introduction to the initial structure of private investment fund regulation in Part II that later forms the basis for distinguishing the intensity of regulatory change in each of the three phases, Part III begins with a discussion of regulatory changes in phase one and the implications of LTCM. Part IV emphasizes the examination of regulatory changes in the aftermath of the Dodd-Frank Act, its effects on the private investment fund industry, systemic risk implications and changes in the assessment of private funds' systemic risk in the aftermath of the DoddFrank Act, and new findings in the context of private fund investor due diligence. Finally, Part V examines the evidence on the confluence of hitherto separate asset classes, especially the evidence pertaining to the confluence of private and mutual funds. Part $\mathrm{V}$ also examines the implications of confluence of assets classes for the public/private distinction in federal securities regulation. Part VI examines the implications of private fund managers' use of blockchain technology and the associated innovation trends in the private investment fund industry. Part VII concludes.

\section{INITIAL REGULATORY FRAMEWORK IN THE UNITED STATES}

Private investment funds in the United States began operations as privately held and privately managed investment funds that were unregistered and exempt from federal securities regulation. ${ }^{14}$

\section{A. Reliance on Exemptions}

In the early 1950s, organizers of private investment funds designed the funds to be exempt from the registration requirements of the Investment Company Act of 1940 (private investment funds are not mutual funds), the registration requirements of the Investment Advisers Act of 1940 (private fund advisers are not classified as public investment advisers), the public offering registration requirements of the Securities Act of 1933 ("33 Act") (no public offering is required), and the periodic reporting requirements of the Securities Exchange Act of 1934 ("34 Act”) (private investment funds

of the hedge fund industry relative to alternative asset classes).

13. See generally Kaal, Confluence, supra note 5; Kaal \& Anderson, Protection, supra note 12 .

14. Kaal \& Oesterle, supra note 8, at 1-2 ("The originators of the early funds designed the funds to maximize their freedom to employ complex trading strategies by minimizing their exposure to regulation under various federal statutes. Characteristics of early hedge funds included their ability to remain unregistered and exempt from federal securities regulation."). 
are not publicly traded companies). ${ }^{15}$ Private investment funds also avoid classification as financial market intermediaries that are specifically regulated by federal legislation, including underwriters, market makers, broker-dealers, banks, or investment subsidiaries of operating companies. By having fewer than 500 investors, private investment funds also generally avoid the periodic reporting obligations of section 12 of the Exchange Act and SEC Rule 12g-1.

Private investment funds traditionally also relied on the "private offerings" exemption under the 33 Act and the "safe harbor" provision in Rule 506 of Regulation D. Reliance on these exemptions allows private investment funds to market themselves only to accredited investors, who are institutional investors, insiders, or natural persons with a net worth of over $\$ 1$ million or income of over $\$ 200,000$ for each of the last two years. ${ }^{16}$ Private investment funds using Rule 506 could not use any form of general solicitation or general advertising. The SEC applied a pre-existing, substantive relationship test when deciding that the general solicitation rule had not been violated. The traditional restrictions in Rule 506 have been relaxed under the JOBS Act.

The Investment Company Act of 1940 contains the most important regulatory exemption for private investment funds. Private investment funds rely on one of two statutory exclusions in the definition of an investment company. Either they have fewer than 100 investors or their investors are qualified purchasers. ${ }^{17} \mathrm{~A}$ hedge fund that qualifies for one of these statutory exclusions may use investment techniques, such as shorting, among others, that are prohibited for registered investment companies.

Through the structuring of their operations, private investment funds can also avoid additional otherwise applicable regulations. Private investment funds avoid regulation under the Employee Retirement Income Security Act ("ERISA") by limiting the ownership interest of any employee benefit plan to less than $25 \%$ of the fund. Private investment funds also typically avoid the regulation of "commodity pools" by the Commodity Futures Trading Commission ("CFTC"). New CFTC rules exempt pools that sell only to sophisticated participants, "accredited investors" under Regulation D, or "qualified purchasers" under the Investment Company Act.

Despite the broad application of exemptions and avoidance of certain rules by way of structuring operations, private investment funds are still subject to the general legal framework applicable to financial institutions. Such regulations include the antifraud provisions of the 33 and 34 Acts, state

15. Id. at 7 .

16. Id. at 5 .

17. "Qualified purchasers" refers to individuals who own more than $\$ 5$ million in investments or companies with more than $\$ 25$ million in investments. Id. at 6 . 
law prohibitions against investor fraud, insider trading prohibition under Rule 10b-5, and applicable banking laws restricting the activities of private investment fund lenders. ${ }^{18}$

\section{B. Evolution of the Investment Advisers Act Exemption}

The controversial nature and evolution of the registration exemptions and safe harbor under the Investment Advisers Act of 1940 underscore their policy relevance. The registration exemptions and safe harbor under the Investment Advisers Act of 1940 and the applicable SEC guidance have traditionally allowed advisers to private investment funds to avoid registration as investment advisers with the SEC. ${ }^{19}$ Until the passing of the Dodd-Frank Act in 2010, the safe harbor allowed investment advisers to private investment funds to manage large amounts of securities indirectly for several hundreds of investors in several funds. ${ }^{20}$ Under the safe harbor, investment advisers to private investment funds were able to count a legal organization as a single client, provided the investment advice was based on the objectives of the legal organization, rather than the individual investment objectives of any owners of the legal organization.

The controversy over private fund adviser registration requirements started in 1969. Because of private investment funds' alleged involvement and impact on the 1969 bear market, the SEC started to consider opportunities to increase the regulatory scrutiny of the industry. While the SEC initially opined that hedge funds were "dealers" in securities, which could require registration under the Securities and Exchange Act of 1934, ${ }^{21}$ its guidance in the form of no-action letters continued to support the private fund industry in determining how to count clients to stay exempt from securities regulation until 1985.

Finally, in 1985, in an attempt to clarify the no-action letter guidance and provide private investment fund advisers with greater certainty in determining when they might rely on the safe harbor, the SEC adopted the investment adviser registration safe harbor in Rule 203(b)(3) under the Investment Advisers Act of $1940 .^{22}$ The safe harbor allowed a limited partnership, rather than each of its limited partners, to be counted as a "client" of a general partner acting as investment adviser to the partnership.

18. See id. at 7 (pointing out the SEC's interest in bringing hedge funds under its regulatory authority).

19. Kaal, Basel III, supra note 7, at 412-14.

20. Id. at 414; Kaal, Registration, supra note 9, at 256-57; Kaal \& Oesterle, supra note 8 at $7-8$

21. Kaal \& Oesterle, supra note 8 at 7.

22. Kaal, Basel III, supra note 77, at 412-14; Kaal, Registration, supra note 9, at 25657; Kaal \& Oesterle, supra note 8 at 7-9. 
The SEC reasoned that if an investment adviser manages an investment pool on the basis of the investment objectives of its participants, the entire pool should be viewed as the adviser's client, rather than each participant. ${ }^{23}$

In December 2004, in an unprecedented politically-motivated reversal of existing safe harbor rulemaking, the SEC, using its rulemaking authority under the Investment Advisers Act of 1940, issued a final rule that required the overwhelming majority of previously unregistered private investment fund advisers to register with the SEC, giving it enhanced oversight over the industry. ${ }^{24}$ Hedge fund advisers strongly opposed this controversial rule. ${ }^{25}$ Without the private adviser exemption and as newly registered advisers, private investment fund advisers were subject to SEC inspections and bookkeeping and record keeping requirements. Private investment funds were now faced with disclosure requirements and code of ethics requirements resulting in substantially higher legal fees. Registration also allowed the SEC to screen private investment fund advisers for prior convictions or other professional misconduct.

The registration requirement precipitated substantial opposition by the hedge fund industry. Eventually, in July 2006, the D.C. Circuit in Goldstein v. $S E C$ vacated the hedge fund rule as an instance of arbitrary rulemaking by the SEC. ${ }^{26}$ Because the term "client" had not otherwise been defined in the Investment Advisers Act, the SEC had no authority to determine the meaning of the term. Most hedge fund advisers who had registered under the registration rule deregistered. ${ }^{27}$ After the Goldstein decision, the SEC proposed additional accredited investor standards under Regulation D and dramatically expanded antifraud protection for investors.

23. Kaal \& Oesterle, supra note 8 at 8 ("The SEC broadened the scope of the rule in 1997 by including other entities used by investment advisers to pool client assets. Although the 1985 Rule permitted advisers to count each partnership, trust, or corporation as a single client, the 1997 Rule expanded the rule to cover other legal entities. Specifically, investment advisers could count a legal organization as a single client provided the investment advice was based on the objectives of the legal organization rather than the individual investment objectives of any owners of the legal organization. This safe harbor allowed investment advisers to manage large amounts of securities indirectly for several hundreds of investors in several hedge funds.").

24. See id. at 9 (providing that the SEC's rule was motivated to increase information on hedge fund advisers, deter fraud, and improve compliance due to the growth of the hedge fund industry, increased hedge fund risk, and financial loss to investors from fraudulent activity by advisers).

25. See Kaal, Registration, supra note 9, at 244-45, 249, 258-61 (stating that 91 of the 124 letters submitted to the SEC regarding the rule were against the proposal); Kaal \& Oesterle, supra note 8 at $8-9$ (explaining that advisers were subject to SEC inspections and bookkeeping requirements without the private adviser exception).

26. Kaal, Evolution, supra note 4, at 1156; Kaal, Basel III, supra note 7, at 414-16; Kaal, Registration, supra note 9, at 247, 260-61; Kaal \& Oesterle, supra note 8 at 9.

27. Kaal, Basel III, supra note 7, at 416, 428-29; Kaal, Evolution, supra note 4, at 1157. 


\section{FAILURE OF LONG-TERM-CAPITAL MANAGEMENT}

The failure of LTCM was the most publicized case of a failure of a private investment fund and the significance of a failure for the stability of world financial markets. ${ }^{28}$ Right after the announcement of the Russian debt moratorium in mid-August 1998, LTCM suffered losses of $\$ 1.8$ billion, bringing its loss of equity for the year to over $50 \%{ }^{29}$ Because banks and brokers had allowed LTCM to borrow $100 \%$ of the value of its collateral prior to the worsening of LTCM's financial condition in 1998, LTCM's $\$ 4.8$ billion in capital dissipated quickly when the banks began to make margin calls. In order to stay afloat, LTCM required a large capital injection. However, because of the size of its debts, LTCM's creditors would likely have been pushed into insolvency if LTCM had been allowed to file for bankruptcy. The already unstable world credit markets in 1998 would likely have collapsed if LTCM's creditors had liquidated their LTCM collateral to the value of $\$ 1$ trillion to recoup their costs. ${ }^{30}$ Realizing the effect of allowing LTCM to file for bankruptcy on other market participants, the Federal Reserve Bank of New York orchestrated a bailout of LTCM with fourteen leading investment banks committing between $\$ 100$ million to $\$ 350$ million each. ${ }^{31}$

LTCM's failure and its effect on world financial markets raised regulators' awareness of the risks pertaining to private investment funds ${ }^{32}$ and the risk tolerance of banks, prime brokers, and other counterparties to private investment funds. ${ }^{33}$ Because private investment funds take risks that other financial participants and other counterparties to banks would not, borrow massive amounts, and are willing to pay a premium for borrowing, banks' managements generally view private investment fund banking relationships as desirable. However, banks overexposed themselves to private investment fund lending, allowing LTCM and other private investment funds to grow significantly. As counterparties to private investment funds, such as LTCM, banks put their own existence at risk with

28. Kaal, BANKING SUPERVISION, supra note 1, at 52.

29. While LTCM at the time of its collapse had around $80 \%$ of its assets under management (AUM) in government bonds of G7 countries, it also traded on and off-exchange derivatives in interest rates, equity products, and foreign exchange, controlling \$160 billion in stocks and bonds, $\$ 4.8$ billion in capital, and derivatives with a notional value of $\$ 1$ trillion. Id. at 53-54.

30. Id. at $56-57$.

31. Id. at 57 . The consortium injected $\$ 3.6$ billion in private equity into LTCM and received a $90 \%$ stake in $\mathrm{LTCM}^{\prime}$ 's portfolio and operational control in return.

32. The LTCM failure illustrated the dangerous combination of high leverage, large positions, funding illiquidity, inadequate risk management, investor redemptions, and insufficient monitoring of fund credit quality by counterparties. $I d$. at 57 .

33. Id. at 58-72,133-71. 
their lending practices.

\section{A. Critique of Regulatory Proposals}

Scholarly engagement with the topic of private investment fund regulation increased markedly in the aftermath of the failure of LTCM in $1998 .^{34}$ Whereas prior to the LTCM debacle the literature had mostly evaluated the model approaches to private investment fund regulation, including coordinated international cooperation, national direct regulation, indirect regulation, and prudential regulation, ${ }^{35}$ post LTCM all leading international and domestic regulatory bodies reviewed regulatory approaches in an attempt to improve the regulatory framework for private investment funds. ${ }^{36}$

International and domestic regulatory bodies proposed reform of the regulatory framework for private investment in an attempt to address the perceived regulatory shortcomings identified by the failure of LTCM. Most of the proposals for regulatory improvements involved some of the following elements: financial intermediaries' risk management; risk management of private investment funds; improvements for the role of regulators in individual financial intermediaries with significant private investment fund business, especially firms' risk management; improvements in market practices at the industry and firm levels, and improvements in transparency, e.g., reporting and disclosure recommendations. ${ }^{37}$

Starting in 2005, this author critiqued the proposals to remedy the regulatory framework for private investment funds post-LTCM. ${ }^{38}$ He found that proposals involving clearer credit risk strategies and credit risk management policies and processes for financial intermediaries were inappropriately applied across the range of business models and lacked concrete implementation elements. Proposals calling for credit departments for financial intermediaries proved very costly. Increased stress tests, Value at Risk, and Monte Carlo scenarios for financial intermediaries to private

34. Id.

35. Id. at $48-51$.

36. Id. at 133-71 (summarizing and evaluating regulatory proposals issued by the Basle Committee on Banking Supervision, the International Organization of Securities Commissions, the Board of Governors of the U.S. Federal Reserve System, the U.S. President's Working Group on Financial Markets, the Counterparty Risk Management Policy Group, the Multidisciplinary Working Group on Enhanced Disclosure, the Hedge Fund Industry Group, the Committee on the Global Financial System, the International Swaps and Derivatives Association, and the Financial Stability Forum Working Group on Highly Leveraged Institutions).

37. Id. at 171

38. Id. at 171-74; Kaal, Basel III, supra note 7, at 408-10, 424-34, 436-39, 444-48, 456-62. 
investments funds necessarily use historical data and are less valuable as an indicator of high risk sensitivity for future events. ${ }^{39}$ Proposals for increased risk management in private investment funds may not adequately take into account evidence on private investment funds' performance in relative secrecy. ${ }^{40}$ Calls for improving the role of regulators in individual financial intermediaries with significant private investment fund business encounter significant transaction costs. Proposals calling for improvements in closeout netting agreements for financial contracts and calls for harmonized standard documentation across jurisdictions may encounter jurisdictional arbitrage and national protectionism. ${ }^{41}$

\section{B. Indirect Regulation}

A core emphasis in this author's scholarly focus post LTCM involved banks' lending exposure to private investment funds as an indirect means of supervising the private investment fund industry. ${ }^{42}$ Banks are ideally positioned to support private investment fund regulation. ${ }^{43}$ Several factors, including the exclusivity, intensity, length, and quality of the relationship between banks and private investment funds influence the level of control a bank may exercise over a private investment fund. ${ }^{44}$ Some private investment fund managers may terminate a lending relationship to avoid a bank's attempts to exercise control over a private investment fund. However, because private investment funds' dynamic trading strategies often depend on the immediate availability of capital; and given today's banking environment with increased scrutiny over lending and lending relationships, managers are unlikely to terminate a lending relationship. ${ }^{45}$

In a 2009-10 scholarly exchange between this author and Professor Roberta Romano, ${ }^{46}$ Professor Romano pointed out that: "[private investment

39. Kaal, BANKING SUPERVISION, supra note 1, at 171-74.

40. Id. at $171-74$.

41. Id. at 171-74.

42. Kaal, Basel III, supra note 7; Kaal, BANKING SuPERVISION, supra note 1.

43. Kaal, BANKING SUPERVISION, supra note 1.

44. Id. at 217-218.

45. Id.

46. See Wulf A. Kaal \& Christian Kirchner, Economics of Financial Market Regulation: Financial Reporting Standards, Banking Regulation, and Hedge Funds, in LAW AND Economics of Global Financial Institutions 5 (Peter Nobel, Katrin Krehan \& AnneCathrine Tanner eds., 2010) (discussing the importance of economic regulations on the banks as the major players in investment); Roberta Romano, Against Financial Regulation Harmonization: A Comment (Yale L. \& Econ. Res. Paper No. 414, 2010), https://papers.ssrn .com/sol3/papers.cfm?abstract_id=1697348 [https://perma.cc/ZQ9J-LTYG] (arguing that the move to regulate hedge funds more is misguided and that hedge funds were not the cause of the recent financial crisis); Kaal, Basel III, supra note 7. 
funds] manage only a small proportion of the investment universe, particularly as compared to banks' assets and are far less leveraged than banks." ${ }^{47}$ European and United States legislators' attempts at imposing stricter rules on private investment funds, seizing on hedge funds' alleged impact on market stability in the 2008-09 credit crisis could, therefore, have been misplaced.

In response, and in an attempt to show the relevance of indirect regulation of private investment funds via increased regulatory emphasis on banks' lending exposure to private investment funds, this author referenced data on hedge funds' growing participation in managing complex financial instruments, such as CDOs and other derivatives. ${ }^{48}$ The data suggest that since 2000 private investment funds have steadily increased their share in the credit derivatives market while banks' role in the market for credit derivatives has declined. ${ }^{49}$ The increasing role of private investment funds in the credit derivatives market ${ }^{50}$ in combination with the failure of that market in 2009 formed the basis for this author's proposal to increase the regulatory emphasis on banks' lending exposure to private investment funds. ${ }^{51}$

Another indirect form of private investment fund regulation, proposed by this author, focuses on investor suitability criteria. ${ }^{52}$ After evaluating the shortcomings of the then existing numerical wealth requirements defining qualified investors who were then eligible for investments in private investment funds, ${ }^{53}$ this author suggested in 2009 , e.g., before the regulatory overhaul of private investment fund regulation in Title IV of the Dodd-Frank Act in 2010, that investor suitability standards could help address concerns over the shortcomings of investor eligibility standards. Such proposed investor suitability standards would require independent verification of investors' ability to evaluate highly complex financial products and investment risk, rendering wealth as a proxy for sophistication redundant for investor eligibility. ${ }^{54}$

47. Kaal, Basel III, supra note 7, at 454 .

48. Id. at 454-55.

49. Id. at 455 (Table 1).

50. Id. at 455 (Table 1).

51. Id. at $448-62$

52. Kaal, Retailization, Regulation, and Investor Suitability, supra note 7.

53. Id. at 636-37 ("The numerical wealth requirements that are currently in place to define qualified investors... do not take into account that even investors who would otherwise fulfil the numerical wealth requirements do not always have the adequate level of knowledge, understanding and sophistication that would be required for investing in highly complex financial instruments. Recent proposals by the SEC to toughen the numeracy wealth requirements for hedge fund investing fail to ascertain the appropriate level of sophistication and adequate understanding of highly complex financial instruments.").

54. Id. at 637 


\section{DODD-FRANK-ACT}

In an unprecedented overhaul of the regulatory environment for private investment funds advisers in the United States, the Dodd-Frank Act in effect overruled all previous SEC rules and legal precedent on private investment fund adviser registration exemptions. ${ }^{55}$ Dodd-Frank added a significant new chapter in the debate on private investment fund adviser registration. ${ }^{56}$

Title IV of the Dodd-Frank Act is entitled the Private Fund Investment Advisers Registration Act of 2010 ("PFIARA"). PFIARA authorizes the SEC to bring private investment funds under regulatory supervision. ${ }^{57}$ PFIARA mandates private investment fund adviser registration to increase record keeping and disclosure. Under PFIARA, private investment fund advisers with more than $\$ 150$ million assets under management ("AUM") must register as investment advisers and disclose information about their trades and portfolios to the SEC ${ }^{58}$ The Dodd-Frank Act also directs the SEC to set up rules for the registration and reporting of private investment fund managers who were previously exempt from registration. ${ }^{59}$

As part of the new rules, the SEC introduced controversial reporting obligations in a form called Form PF (private funds). ${ }^{60}$ Form PF requires investment managers to disclose information about themselves, the funds they manage, and their investors. ${ }^{61}$ The unprecedented disclosures in Form

55. See supra notes Error! Bookmark not defined.-Error! Bookmark not defined. and accompanying text.

56. Kaal, Basel III, supra note 7, at 410-36; Kaal, Registration, supra note 9, at 261-73; Kaal \& Oesterle, supra note 8 at 9-15; Kaal, Evolution, supra note 4, at 1158-59.

57. Kaal, Evolution, supra note 4, at 1157-58.

58. Id. at 1158-65. By registering private investment fund advisers, the SEC intends to collect necessary information to curtail those who operate in the "shadows of our markets," prevent fraud, limit systemic risk, and provide information to investors.

59. Id. at 1157-58; Kaal, Hedge Fund Manager Registration, supra note 9, at 249, 262.

60. Kaal, Evolution, supra note 4, at 1159, 1163-65; Kaal, Registration, supra note 9, at 269-73.

61. U.S. Sec. \& Exch. Comm'n, FORM PF: REPORTING Form FOR INVESTMENT AdVISERS TO Private Funds AND CERTAIN COMMOdity POOL Operators AND COMMODity TRADING ADVISORS, available at http://www.sec.gov/about/forms/formpf.pdf [https://perma.cc/NTV8V4RC]. Form PF disclosure requirements include a breakdown of the net asset value (NAV) that the investment manager manages, including the percentage of the reporting fund's NAV that was managed using high-frequency trading strategies. Form PF requires investment advisers to disclose the five trading counterparties to which the reporting fund has the greatest net counterparty credit exposure and the dollar amount owed to each creditor. It also requires that the manager identify changes in market factors and their effect on the portfolio's long and short components as a percentage of NAV. Additional disclosures include any information about the counterparties' collateral and other credit support posted to the respective reporting funds, as well as trading and clearing mechanisms subject to liquidity constraints and the duration of those constraints. Form PF is also intended to improve the SEC's understanding of reporting funds' liquidity, exposure, and assets. Accordingly, Form 
PF that made it so controversial in the industry include the disclosure of strategies and products used by the private investment fund adviser and its funds, performance and changes in performance, financing information, risk metrics, counterparties and credit exposure, positions held by the investment adviser, percent of assets traded using algorithms, and the percent of equity and debt, among other matters. ${ }^{62}$

In light of the highly sensitive and controversial nature of these required disclosures and the complexity of the reporting requirements, Form PF created substantial challenges for the hedge fund industry. Arguing that the mandatory private investment fund disclosure requirements in Form PF could inappropriately burden the private investment fund industry, private investment fund advisers have traditionally opposed enhanced transparency of the funds they manage. ${ }^{63}$ While the disclosures in Form PF were private, i.e., only the SEC and not the public had access, the industry feared that such information could at some point in the future be made public, which would largely eliminate private investment fund managers' ability to make absolute returns for their clients, as competitors would be able to reverse engineer their strategies. Apart from concerns about publicity, the private investment fund industry complained that many reporting provisions on Form PF used industry terms inconsistently and many required disclosures were rather hard to produce. ${ }^{64}$ For instance, the disclosure of counterparty credit exposure is sensitive information that often cannot readily be determined by the individual private investment fund managers.

In a concerted effort to enforce the Dodd-Frank Act provisions pertaining to the private investment fund industry, the SEC increased examinations and enforcement actions against private investment fund

$\mathrm{PF}$ requires investment advisers to disclose the time increments needed to liquidate a certain percentage of the reporting fund's portfolio, the dollar value of long and short positions in each asset class, the value of turnover by asset class, the types of creditors and the market value of borrowings from them, and the aggregate value of all derivative positions for each advised fund. Finally, Form PF requires disclosure of the reporting fund's restrictions (if any) on investor withdrawals and redemptions and other information pertaining to investor liquidity, such as the percentage of NAV.

62. Id. Private investment fund advisers are also required to provide confidential reports with respect to certain information related to systemic risk, such as trading practices; trading and investment positions; the amount of AUM; valuation policies; side letters; the use of leverage, including off-balance sheet leverage; counterparty credit risk exposures; and other information deemed necessary.

63. See Kaal \& Oesterle, supra note 8 at 11-12 (surveying duties and costs absorbed by investment and hedge fund advisers as a result of Form PF); Kaal, Evolution, supra note 4, at 1164 (discussing the sensitive and complex requirements that Form PF imposes on the hedge fund industry).

64. See Kaal, Evolution, supra note 4, at 1165 (discussing 2012 survey results reflecting the challenges that hedge fund advisers faced as a result of Form PF, and noting that advisors found reporting requirements ambiguous). 
advisers. ${ }^{65}$ In its enforcement efforts in the aftermath of the enactment of the Dodd-Frank Act, the SEC emphasized the equitable allocation of expenses among investment advisers' portfolio funds, the allocation of investment opportunities among private investment fund advisers' clients, and fund advisers' personal investing and outside business activities. ${ }^{66}$

These enforcement trends foreshadow further intensifying regulatory enhancements pertaining to the private investment fund industry. In light of SEC guidance in public statements, it is reasonable for the private investment fund industry to expect longer and more intrusive SEC examinations, further enhanced regulations, and increased SEC enforcement actions against private investment fund managers. ${ }^{67}$ The Department of the Treasury's proposed rule targeting investment advisers' filing and reporting requirements about money laundering, Form ADV disclosures, and the definition of "accredited investor," among other non-final rules in 2015, provide a taste of possible future developments for the industry. ${ }^{68}$

\section{A. Implications of Title IV-Empirical Evidence}

Given the highly controversial nature of Title IV and the private investment fund industry's claims pertaining to its detrimental effect on the industry, this author examined the impact of Title IV in several empirical studies. ${ }^{69}$

\section{Hedge Fund Manager Registration Under the Dodd-Frank Act}

In the first survey study ${ }^{70}$ conducted right before the registration effective date under Title IV, March 30, 2012, this author and a team of four research assistants contacted a population of 1,267 private fund advisers who

65. Id. at 1173-76.

66. Id. For example, significant enforcement actions against private funds from 2012 to 2015 include undisclosed conflicts of interest, actions for misallocation of expenses, and inflating the values of certain illiquid assets that hedge funds and private funds hold. SEC enforcement actions included enforcement of Rule 206(4)-7, which requires funds to adopt, implement, and annually review compliance policies. Moreover, the SEC settled charges with private investment managers who received accelerated portfolio company monitoring fees from sales and initial public offerings (IPOs) of portfolio companies and who failed to disclose conflicts arising from the manager's conversion of portfolio company monitoring fees that could have partially been offset.

67. Id. at 1176 .

68. Id.

69. Kaal, Evolution, supra note 4; Wulf A. Kaal, The Private Fund Industry Five Years After the Dodd-Frank Act - A Survey Study, 35 ReV. Banking \& FIn. L. 624 (2016) [hereinafter Private Fund Industry]; Kaal, Registration, supra note 9.

70. Kaal, Registration, supra note 9, at 249. 
registered with the SEC before the registration effective date. The author contacted the entire population via fax, an electronic survey via email, and phone interviews. Respondents $(n=94)$ answered questions designed to evaluate the long-term effects of reporting and disclosure rules on private funds and the private fund industry. ${ }^{71}$ The survey questions assessed strategic responses of the hedge fund industry to Title IV, investigated the possible long-term effects of hedge fund registration, quantified compliance costs, assessed compliance measures, investigated the implications of disclosure requirements in the Dodd-Frank Act pertaining to hedge funds, evaluated the effect of the regulatory regime on AUM, and assessed the effect of the regulatory regime on profitability.

The results reported in this study suggested that the Dodd-Frank Act registration and disclosure requirements and the SEC's implementation of these requirements created several areas of concern for the hedge fund industry. ${ }^{72}$ Despite these concerns, the hedge fund industry appeared to be only moderately affected and seems to be adapting well to the regulatory environment after the enactment of the Dodd-Frank Act. ${ }^{73}$

More specifically, this first survey study shows that $46.34 \%$ of those who responded indicated that the Dodd-Frank registration and disclosure rules created higher costs that affected the funds they managed, while $78.26 \%$ of respondents stated that the profits of their investment management company were affected. ${ }^{74}$ According to $87.50 \%$ of the respondents, the profits of their investment companies were affected by increased costs as a result of the registration and reporting requirements. A majority of respondents engaged in the following activities: (1) outsourced compliance work, (2) hired additional counsel, (3) instituted new recordkeeping policies, (3) hired additional staff, (4) changed marketing materials, and (5) changed communications with investors. A minority of respondents changed their funds' legal structures in response to the registration and disclosure requirements.

Despite the concerns identified in the first study, the hedge fund industry appeared at the time of the study to be only moderately affected by the Dodd-Frank reporting and disclosure requirements and adapted well to the then new regulatory environment. ${ }^{75}$ The results demonstrated that $82.02 \%$ of respondents at the time did not take the current regulatory regime into account in determining the AUM size of their funds, and $72.09 \%$ of survey respondents did not plan a strategic response to the Dodd-Frank Act

\footnotetext{
71. Id. at 275 .

72. Id. at 315 .

73. Id. at $315-16$

74. Id. at 315 .

75. Id. at $315-16$.
} 
registration and reporting requirements. ${ }^{76}$ Firms that planned a strategic response were smaller than those firms that did not plan a strategic response. Of those who responded, $76.09 \%$ stated that their investors' rate of return was not affected by the registration and disclosure requirements. ${ }^{77}$

A majority of advisers in the first survey study quantified the cost of compliance in a range from $\$ 50,000$ to $\$ 200,000 .^{78}$ However, a significant minority estimated that the total compliance cost would range between $\$ 200,000$ to over $\$ 400,000 .^{79}$ Although a majority of advisers spent fewer than 500 hours to comply with the new registration and reporting requirements, many fund advisers estimated it will take them between 500 and 1000 hours to comply with the requirements. The hours needed to comply with all federal rules and regulations pertaining to hedge fund advisers range from under 100 up to 4000 hours, with a majority of responses ranging from over 300 hours to 800 hours. $^{80}$

A majority of respondents did not feel the need to change the size of their AUM, and Dodd-Frank Act regulations were not factors a majority of respondents considered if they did change the AUM size of their funds. For $80.46 \%$ of respondents, the Form PF threshold for quarterly reporting of $\$ 1.5$ billion AUM was not taken into account in determining the appropriate size of AUM for the funds they manage. ${ }^{81}$ A majority of the $19.54 \%$ of respondents who would take the Form PF threshold into account plan to stay under the Form PF threshold for quarterly reporting of $\$ 1.5$ billion AUM. ${ }^{82}$

Anecdotal evidence collected during the course of the survey study suggested that the information disclosed by hedge fund advisers in required Forms ADV and PF could then be presented by advisers and third party service providers in ways that in effect "flatten out" and "sanitize" the disclosures. ${ }^{83}$ Although the level of sanitizing of disclosures could not be verified, sanitized disclosures could be less useful for Financial Stability Oversight Council (FSOC) and SEC evaluation and their determination of the systemic risk posed by private funds. ${ }^{84}$

To summarize, the results of the first survey study in 2013 suggested that the private fund industry had been adjusting well to the registration and disclosure requirements for private fund advisers introduced in Title IV in

\footnotetext{
76. Id. at $315-16$.

77. Id. at 316 .

78. Id.

79. Id.

80. Id.

81. Id.

82. Id.

83. Id.

84. Id.
} 
2012. ${ }^{85}$ The impact of the registration and disclosure rules appeared to be much less intense than the industry initially anticipated. Although hedge fund advisers seemed to absorb the reported cost implications of registration and disclosure rules relatively quickly after registration, the long-term cost implications of registration and reporting obligations still had the potential to affect the private fund industry in the long run.

Because the data for the first study had been collected within three months after the registration requirements in Title IV took effect, the author knew that future survey studies would be needed to determine the long-term impact of the Dodd-Frank Act. ${ }^{86}$

\section{Private Fund Industry Five Years After the Dodd-Frank Act}

In a second study, this author evaluated the long-term implications of the unprecedented yet evolving post Dodd-Frank Act regulatory framework pertaining to the private fund industry. ${ }^{87}$ The study helps clarify the relevant long-term implications of the fundamental reshaping of the regulatory landscape for the private fund industry through both the Dodd-Frank Act and the JOBS Act. For the second study, this author and a team of research assistants collected and coded data for a population of 1,267 registered investment advisers. Respondents $(\mathrm{N}=69)$ answered questions in several categories designed to identify cost, compliance, and management issues associated with the post Dodd-Frank Act regulatory framework. ${ }^{88}$

The evidence provided in this study supports findings from the author's earlier study suggesting that the industry adapted well to the new regulatory environment in the aftermath of the Dodd-Frank Act. The findings in this study suggested that the industry is mostly affected by the uncertainty and higher costs associated with the Act, but under multiple metrics the industry appeared to be coping well overall with the evolving post Dodd-Frank Act regulatory landscape. ${ }^{89}$

Nevertheless, the findings of this study also show that the Dodd-Frank Act had negative long-term effects on the private fund industry. More than a third of respondents $(34.9 \%)$ opined that Title IV will affect the private fund industry in the next five years because of additional expenses, and nearly a third (32.6\%) opined that it will create barriers to entry to private fund market entrants. Fifty percent of respondents indicated that the DoddFrank registration and disclosure rules have created higher costs that will

\footnotetext{
85. Id.

86. Id. at 316-17.

87. Kaal, Private Fund Industry, supra note Error! Bookmark not defined., at 624.

88. Id.

89. Id. at $624,626-27,631$.
} 
affect their funds in the next five years. The majority of those respondents who believed that Dodd-Frank has affected their fund(s) earnings blamed additional compliance costs associated with Dodd-Frank. A majority of respondents have instituted measures in response to the requirements imposed by Title IV. The most common actions taken included: (1) outsourcing compliance work, (2) hiring additional counsel, (3) instituting new record-keeping policies, (4) hiring additional staff, (5) changing marketing materials, and (6) changing communications with investors. Moreover, a majority of respondents stated that as a result of the post DoddFrank Act regulatory regime, their AUM would need to change. While $18.2 \%$ of respondents would lower their AUM to avoid the regulatory hassle, $27.3 \%$ actually still want to increase their AUM. ${ }^{90}$ Another $27.3 \%$ desire to attain the right size to cover expenses.

Compliance costs were a significant issue for the private fund industry, and the survey helps clarify compliance cost issues associated with Title IV. A majority of respondents found Dodd-Frank compliance costs to range from $\$ 50,000$ to $\$ 200,000$. However, a significant minority estimated that the total compliance costs will range from $\$ 200,000$ to over $\$ 400,000 .{ }^{91}$ A considerable number of respondents estimated the total annual cost to comply with all federal regulations pertaining to the private fund industry at up to $\$ 100,000$. The largest number of respondents $(26.5 \%)$, however, estimated the annual compliance cost for all federal regulations at between $\$ 100,000$ and $\$ 200,000 .^{92}$ A smaller group (14.3\%) estimated the cost of compliance as more than $\$ 400,000$ a year.

Respondents' estimates pertaining to compliance time are consistent with their estimates pertaining to compliance cost. Although a clear majority of adviser respondents spent fewer than 500 hours to comply with Title IV, a noticeable minority $(11.5 \%)$ estimated compliance time at more than 1000 hours. Sixty-five and one-tenth percent of respondents estimated the total time required to comply with all federal regulations at between 100 and 500 hours. However, a significant minority (20.9\%) estimated it above 1000 hours.

The results in several survey question categories suggest that Title IV of the Dodd-Frank Act had a negligible effect on the private fund industry. Most importantly, $65 \%$ of private fund adviser respondents believed that their fund earnings were not affected by Title IV, and 75.4\% opined that profits were not affected by the increased compliance requirements in Title IV. A majority $(74.5 \%)$ of private fund adviser respondents do not plan a strategic response to Title IV of the Dodd-Frank Act. A majority of

90. Id.

91. Id.

92. Id. 
respondents did take the regulatory regime into account before Dodd-Frank, implying that Dodd-Frank did not make much difference in the way respondents run their business. However, of those who responded, 70.6\% would not take the current regulatory regime into account in determining the AUM size of their funds. While a majority of respondents (33.3\%) prefer an AUM size of between $\$ 500$ million and $\$ 1$ billion, no clear majority emerges as to the preference pertaining to the $\$ 1.5$ billion Form PF quarterly reporting threshold for larger funds. And, a majority of adviser respondents (66.7\%) did not take the $\$ 1.5$ billion AUM threshold under Form PF for quarterly reporting into account in determining the appropriate size of AUM for the fund(s) they manage. While $26.5 \%$ of respondents opined that there was no impact on their AUM preference, target investment opportunities and additional expenses did influence respondents' AUM preferences. Moreover, private fund advisers in the sample did not terminate existing employment relationships. Few respondents severed an advising relationship, changed funds' (legal) structure, liquidated positions, changed investment styles, changed portfolio structure, or closed funds to new investors.

Based on the findings in this study, the SEC's attempts at clarifying and optimizing the legal framework post Dodd-Frank Act effectively supported the industry in its efforts to comply with the revised standards. At the same time, there is sufficient evidence in the findings of this study suggesting that the SEC's implementation and clarification of Dodd-Frank Act registration and reporting requirements for private funds also created uncertainty and higher costs for the industry.

In summary, the second survey study shows that the private investment fund industry had adjusted well to the Title IV requirements. The long-term impact of the evolving post Dodd-Frank Act regulatory landscape appeared to be much less intense than the industry initially anticipated. ${ }^{93}$ The longterm cost implications of registration and reporting obligations as reported in this study appear to be absorbed relatively quickly after registration. ${ }^{94}$

\section{Private Fund Disclosures Under the Dodd-Frank Act}

Because the first survey study in the private investment fund manager registration context left many issues pertaining to private investment fund disclosures open, the author conducted a follow-on study in $2015 .{ }^{95}$ More specifically, because this author's prior studies suggested that the SEC's

93. Id.

94. Id. at 666-67.

95. See generally Kaal, Private Fund Disclosures, supra note 9 (examining the consequences of the disclosure requirements on the private fund industry). 
mandated collection of private fund data in Form PF created several core challenges for the private fund industry and for the SEC, the follow-on survey focused on the Dodd-Frank-mandated SEC collection of sensitive proprietary information from private fund advisers. The key findings of the follow-on study quantified, evaluated, and clarified many core open issues with respect to the SEC's efforts to collect private fund data through Form $\mathrm{PF}$, including data in relation to: (1) the required resources for completing Form PF, (2) shortcomings of and SEC guidance on Form PF (3) adequacy of filers' reporting systems and service providers, and (4) issues associated with investor relations. The author worked with the SEC in the context of the follow-on study to ensure that the SEC's most pressing concerns pertaining to then new Form PF were included in the survey instrument.

The key findings of the follow-on study indicated that the majority of private fund advisers responding to the survey incurred less than $\$ 10,000$ to prepare their initial data reporting to the SEC, with the cost of subsequent annual Form PF filings at about half the initial cost. ${ }^{96}$ Larger private fund advisers, required to file quarterly, were faced with substantially higher compliance costs, both for their initial data reporting and for subsequent quarterly filings. ${ }^{97}$ While the SEC appeared to have overestimated the costs of Form PF compliance for larger private fund advisers, the data analysis in the follow-on study affirmed SEC cost estimates for smaller private fund advisers' Form PF compliance costs. ${ }^{98}$

The data analysis in the follow-on study suggested that the overall effect of private fund disclosure requirements on the private fund industry was moderate but could be further improved. The majority of SEC-registered private fund advisers identified the ambiguity of Form PF data reporting requirements as the most pressing issue. ${ }^{99}$ However, the majority of respondents also considered their existing reporting systems adequate for capturing the information required by the SEC and agreed with the SEC's definitions and instructions for Form PF.

Several survey questions pertained to the purpose of Form PF and required filing resources. Respondents identified the SEC's objective of assessing systemic risk and the historical lack of private fund information provided by the industry to the SEC as the primary purposes of Form PF disclosure requirements. ${ }^{100}$ Commenters also argued that FSOC and Office of Financial Research (OFR) monitoring of risk, investment adviser examinations, and the collection of risk exposure information were

\footnotetext{
96. Id. at $431,469,471$.

97. Id. at 469 .

98. Id. at $447-48$

99. Id. at $431,454,470$.

100. Id. at 445,464 .
} 
important purposes in the enactment of Form PF. ${ }^{101}$

The completion and filing of Form PF required the commitment of resources from and expenditures by the private fund industry. A majority of respondents (59.18\%) stated that the additional expenditures required to complete and file Form PF for the first time were under $\$ 10,000 .{ }^{102} \mathrm{~A}$ majority of commenters (57.14\%) identified the cost of subsequent annual Form PF filings at about half of the first-time filing cost, i.e., around \$5,000. A breakdown of respondents by AUM suggested that larger private fund advisers, required to file quarterly, were faced with substantially higher compliance costs, both for their initial data reporting and for subsequent quarterly filings. ${ }^{103}$ The data does not identify the long-term costs for the private fund industry of having to complete and file Form PF on an annual or quarterly basis.

The overall expenses necessary to complete and file Form PF correspond with resource requirements, such as the staff required to file Form PF and the total number of hours it took to complete Form PF. A majority of respondents $(67.35 \%)$ used only one to three individuals to complete Form PF. Similarly, a majority of respondents $(69.39 \%)$ indicated that it took staff less than 50 hours to complete Form PF. ${ }^{104}$

The survey identified shortcomings in the design, definitions, and guidance of Form PF. Respondents identified the burdensome nature and the ambiguity of Form PF as the most pressing issues with Form PF. ${ }^{105}$ While a majority of respondents $(59.18 \%)$ agreed with the definitions or instructions in Form PF, respondents nevertheless argued that performance measures in Question 17, and counterparties and definitions of counterparties in Questions 22 and 23, required a level of interpretation. ${ }^{106}$ The minority of respondents $(40.82 \%)$ who disagreed with the definitions or instructions in Form PF generally disagreed with the definition of the term "funds." Commenters were equally split on whether Form PF questions pertaining to calculating regulatory assets under management (RAUM) required filers to interpret RAUM for purposes of completing Form PF.

Most respondents appreciated both SEC guidance and SEC flexibility in responding to questions regarding Form PF. A majority of respondents assessed the best level of SEC guidance in the context of their Form PF completion as sufficient or good. ${ }^{107}$ The majority of the commenters who

101. Id.

102. Id. at 447,465 .

103. Id. at $447-48,465$.

104. Id. at 449-50, 465 .

105. Id. at $433,452,465$.

106. Id. at 453,465 .

107. Id. at 429,465 . 
believed that SEC guidance was inadequate indicated that SEC guidance was particularly unclear with respect to Section 1c, Item B (regarding Reporting Funds). This was consistent with the responses that disagreed with the definition of funds in Form PF. Most respondents (72.92\%) agreed that the SEC's flexibility in answering questions with respect to Form PF was helpful. Commenters stated that SEC flexibility was valuable because it enabled respondents to interpret Form PF, it increased respondents' ability to use their own internal methodologies, it helped them articulate their own assumptions, it clarified a lot of questions, and it simplified the completion of the form. ${ }^{108}$

The survey identified the adequacy of private funds' existing reporting systems utilized to capture the information required in Form PF. A majority of respondents $(65.22 \%)$ stated that their existing internal reporting systems adequately capture the information required by Form PF. ${ }^{109}$ More specifically, the majority of respondents did not encounter difficulties in identifying data responsive to questions about counterparty credit exposure, by using counterparties' names on trading and/or legal records. Several respondents $(34.78 \%)$ opined that their existing internal reporting systems were insufficient to respond to questions on Form PF because they require further analysis and calculations.

Survey respondents also largely (72.29\%) abstained from employing a service-provider to complete Form PF. ${ }^{110}$ Firms' ability to use existing internal reporting systems to complete Form PF is consistent with firms' preference for completing Form PF in-house. A majority of respondents actually suggested that Form PF can be completed in-house. Others opined that completing Form PF would not justify the expense of hiring a serviceprovider. Commenters identified several challenges in working with a service-provider, including the investment of time and expenses to develop processes, and the burden of providing service-providers with the required information. The minority of respondents who hired a service-provider stated they did so because of difficulties in aggregating the data and entering it directly without having an internal system to assist in the process; the service providers' knowledge and their industry insight into answer methodology; a desire to ensure consistency in preparation; and the burden of how long it would take to complete Form PF in-house. ${ }^{111}$

In summary, the findings of the follow-on survey study suggested that the overall effect of Form PF data reporting requirements on the private fund industry was less severe than widely expected by the industry. In light of the

108. Id. at 457,465 .

109. Id. at 459,466 .

110. Id. at 461,466 .

111. Id. at 462,466 . 
cost data provided by the study (for both smaller and larger private fund advisers), industry concerns that mandatory private fund adviser registration and disclosure requirements could inappropriately burden investment advisers seemed to be mostly unfounded. The results of the follow-on study complemented earlier findings suggesting that the private fund industry adjusted well to the reporting obligations mandated by Title IV.

Nevertheless, the data analysis and the findings of the study indicated several areas of concern with existing Form PF questions and requirements. Important issues include the ambiguity of several key questions in Form PF; the time constraints required to answer certain questions, such as Question 16 (types of investors), Question 17 (performance), and Question 7 (related persons); respondents' disagreement with the definition of funds; and the lack of adequate SEC guidance for Section 1c, Item B (information regarding reporting fund). ${ }^{112}$ Other issues identified in the study pertain to the insufficiency of existing reporting systems for some firms; difficulties in aggregating the required Form PF data and entering it directly without the availability of a system to assist in the process; and challenges in working with a service-provider, including process development and the burden of providing service-providers with the required information. ${ }^{113}$

\section{Dodd-Frank Act - Comparative Evidence 2012 and 2015}

In an effort to understand the consistency of short-term and long-term surveys on the impact of Title IV of the Dodd-Frank Act, the author's comparative survey study examined the private fund industry's reactions and adjustments to a rapidly evolving regulatory framework three years after the first application of mandatory registration and disclosure rules for private fund advisers under the Dodd-Frank Act. ${ }^{114}$ To add a historical time series perspective via this comparative survey study, the author used two datasets (2012: $\mathrm{N}=94 ; 2015: \mathrm{N}=69$ ) for a population of 1,267 registered investment advisers. The author analyzed and compared survey respondents' short- and long-term estimations of industry effects. ${ }^{115}$ The data suggested that immediate and short-term concerns had given way to adaptation to the changes.

The comparative survey study indicated that compliance costs associated with the evolving regulatory environment for private fund advisers had many unexpected consequences that had the potential to further

112. Id. at $451,453-56,467$.

113. Id. at 467 .

114. Kaal, Evolution, supra note 4, at 1151.

115. Id. at $1151,1154$. 
shape industry practices. ${ }^{116}$ Several developments are particularly noteworthy. While in both the 2012 and 2015 surveys a majority ( $72 \%$ and $75 \%$, respectively) of respondents did not plan a strategic response to Title IV of the Dodd-Frank Act, in 2015 a substantially higher rate of respondents (47\% in 2015 versus $25 \%$ in 2012) suggested that they changed their communications with investors. ${ }^{117}$ This was consistent with anecdotal evidence suggesting that since the 2012 survey, private fund advisers had changed and increased their communications with investors, often based on advice from counsel. In a legal environment where SEC examinations, enforcement actions, and major settlements define the rules promulgated following the enactment of the Dodd-Frank Act, it had become increasingly important for private fund advisers to communicate with investors, emphasizing the effect of these new conditions on fund operations. ${ }^{118}$ The comparative data also suggested that the industry is increasingly doing such work in-house. This is consistent with the SEC's emphasis on COO liability and subsequent enforcement actions since 2012 that have focused on compliance departments. Moreover, the comparative data suggest that since 2012 at least a part of the industry was closing funds to new investors and even changing funds' legal structures in response to the evolving regulatory landscape. ${ }^{119}$

Perhaps the most important findings of the comparative survey study pertained to the comparative and long-term implications of the compliance costs associated with the evolving post-Dodd-Frank-Act regulatory environment and its effect on private fund advisers. ${ }^{120}$ The comparative data suggested that between 2012 and 2015 the industry was subject to an overall higher cost structure. ${ }^{121}$ The annual cost of compliance doubled for many survey respondents, moving from the $\$ 50,000$ to $\$ 100,000$ range to the $\$ 100,000$ to $\$ 200,000$ range. The survey provided evidence that the industry became more effective from 2012 to 2015 in its compliance with obligations related to the Dodd-Frank Act. ${ }^{122}$ However, assuming that compliance hour requirements were a proxy for compliance cost, the comparative data suggested that the cost structure for all federal regulation increased between 2012 and $2015 .^{123}$

Comparative data on the possible impact of the evolving regulatory environment on the AUM of private investment fund advisers facilitated an

116. Id. at 1198 .

117. Id. at $1185,1198-1201$.

118. Id. at 1201 .

119. Id. at 1201 .

120. Id.

121. $I d$.

122. Id. at 1201 .

123. Id. 
analysis of the implications of rulemaking on the industry's evolution. That data suggested that investment advisers of private funds were increasingly taking the regulatory structure into account when determining their AUM. ${ }^{124}$ It showed that the 2015 survey respondents preferred a higher AUM than the 2012 survey respondents. Whereas, in 2012, 29\% of survey respondents had an AUM preference in the range from $\$ 150$ million to $\$ 500$ million, and only $16 \%$ preferred a $\$ 500$ million to $\$ 1$ billion AUM, in 2015 these figures had reversed; only $15 \%$ of respondents had an AUM preference in the range from $\$ 150$ million to $\$ 500$ million, and $33 \%$ of respondents preferred a $\$ 500$ million to $\$ 1$ billion AUM. ${ }^{125}$ While this finding could be partially explained with the higher overall post-Dodd-Frank-Act cost structure for the industry, it was inconsistent with private fund advisers' general tendency to grow AUM to increase profitability.

To ensure that as much as possible of the net management fee becomes compensation for the managers, investment advisers typically try to allocate as many operating expenses to the fund as possible. Nevertheless, the comparative data provided in the survey study suggested that the additional regulatory obligations imposed on the private investment fund industry in the aftermath of the tectonic regulatory shift stemming from the Dodd-Frank Act influenced AUM preferences. From a policy perspective, changing AUM preferences associated with compliance costs could eventually result in consolidations that facilitate cost savings or precipitate a trend towards family offices that do not manage third-party assets.

The impact of the evolving post-Dodd-Frank Act regulatory environment on investment advisers' profitability had raised industry-wide concerns. Nevertheless, the majority of survey respondents in both the 2012 survey (76.1\%) and the 2015 survey (65\%) believed that the Dodd-Frank Act did not affect reporting funds' earnings. ${ }^{126}$ Of those respondents who did believe that the Act affected their reporting funds' earnings, the comparative data suggested that between 2012 and 2015 investment advisers saw the costs on fund earnings increasingly associated with opportunity costs (2012: 9\%; 2015: 32\%) rather than with increased expenses $(2012: 53 \% ; 2015$ : $36 \%){ }^{127}$ This was consistent with anecdotal evidence suggesting that the industry largely absorbed the increased expenses associated with the DoddFrank Act through the increasing use of pass-through expense terms when

124. Id. at $1190-92,1201$.

125. Id. at $1193,1202$.

126. See id. at 1195, 1202 (reviewing the results of a survey looking at how Dodd-Frank influenced AUM preferences, amidst a discussion that investment advisers try to increase the amount of operating expenses allocated to funds).

127. See id. at 1202 (continuing to share the results of a survey used to determine how Dodd-Frank influenced AUM preferences). 
structuring investment adviser and private fund relationships between 2012 and $2015 .^{128}$

The private fund industry had long voiced concerns about the long-term implications of the evolving regulatory environment on investment advisers' reporting funds. The comparative survey study suggested that the long-term effects of that environment were more substantial than the industry and regulators initially anticipated. ${ }^{129}$ A greater percentage of 2015 responses, compared to 2012 responses, made references to "lower returns" and plans to "consolidate or close funds," which seemed to suggest a more substantial effect on reporting funds. ${ }^{130}$ Confirming these trends, 2012 and 2015 estimates predicted the state of the private fund industry over the next five years and also made references to additional expenses and barriers to entry to the private fund market. Whereas in the 2012 survey only $24 \%$ of respondents referenced barriers to entry for small firms, in 2015,33\% made such references.

\section{What Drives Dodd-Frank Act Compliance Costs for Private Funds?}

Using the unprecedented compliance cost estimates from the earlier survey studies, ${ }^{131}$ this author applied multiple regression analyses to evaluate the possible drivers and effects of Title IV Dodd-Frank Act compliance costs on the private fund industry. ${ }^{132}$ Using hand-selected compliance cost estimates from private fund advisers $(\mathrm{N}=94)$, the study showed with two independent datasets that the number of funds managed by private fund advisers was associated with Dodd-Frank Act compliance costs.

The study demonstrated that the size of registered private fund advisers as measured by AUM was not associated with the per-unit cost of Title IV compliance and other independent variables as proxies for cost. These findings were consistent with the hypothesis that the cost of financial

128. See id. (discussing how the survey looking at how Dodd-Frank influenced AUM preferences is consistent with anecdotal evidence).

129. See id. at 1202 (arguing that the survey examining how Dodd-Frank influenced AUM preferences indicates that Dodd-Frank had a more extreme impact than regulators expected)

130. Id. at $1197,1199,1202-03$.

131. Survey results indicate that the majority of hedge fund advisers and private fund advisers expect Dodd-Frank related compliance costs to range from $\$ 50,000$ to $\$ 200,000$. See Kaal, Registration, supra note 9, at 298; Kaal, Private Fund Industry, supra note Error! Bookmark not defined., at 650; Kaal, Evolution, supra note 4 at 1186.

132. See Kaal, Compliance Costs, supra note 9, at 8 (describing the study design, which included four dependent variables with data obtained from prior surveys: cost of compliance, median cost measures, annual time required for compliance, and median annual time measures for compliance). 
regulation under the Dodd-Frank Act brought increasing returns to scale. ${ }^{133}$ These results of the study confirmed the findings in other studies suggesting that regulatory compliance costs can bring increasing returns to scale. ${ }^{134}$

A significant long-term implication of the results included the creation of barriers to entry for smaller private fund advisers. In other words, if Title IV compliance costs bring increasing returns to scale because the costs of Title IV compliance favor larger firms, Title IV requirements may contribute to the creation of barriers to entry for smaller private fund advisers. ${ }^{135}$ This author demonstrated in this study that barriers to entry also mean that smaller private fund advisers could get forced out of the market or consolidate with other private fund advisers. Consolidation of smaller private fund advisers, in turn, can contribute further to an already existing trend towards private fund adviser consolidation.

The study introduces for the first time possible dynamic elements in the regulation of the private investment fund industry. The literature on dynamic regulation emphasizes adaptable institutions and rulemaking processes to overcome suboptimal governance outcomes. ${ }^{136}$ Rules can become adaptable if institutions and rulemaking processes integrate feedback effects, including feedback effects between the industry and regulators, that produce timely, relevant, and decentralized information for rulemaking ex-ante before rulemakers finalize rules. ${ }^{137}$ By increasing the availability of relevant

133. See id. at 22-23 (discussing the results of the multiple regression, including how the increasing returns to scale result from a high up-front regulatory cost with significantly less costly subsequent reporting obligations).

134. See id. at 23 (synthesizing the results of the multiple regression with prior research).

135. See id. at 23 (explaining why compliance costs impose a barrier-on-entry to smaller firms).

136. See e.g., Wulf A. Kaal, Evolution of Law: Dynamic Regulation in a New Institutional Economics Framework, in FESTSCHRIFT ZU EHREN VON CHRISTIAN KIRCHNER 1211 (Wulf A. Kaal, Matthias Schmidt \& Andreas Schwartze eds., 2014); Wulf A. Kaal, Dynamic Regulation via Governmental Contracts, in ROBERT WALDBURGER ET AL., LAW \& ECONOMICS: FeStSChrift für Peter Nobel Zum 70 Geburtstag 65, 66 (2015) (advocating for the use of governmental contracts to enable feedback processes, which in turn facilitate institutionspecific ex-ante experimentation that allow for rulemaking to adapt to future contingencies); Wulf A. Kaal \& Erik P.M. Vermeulen, How to Regulate Disruptive Innovation - From Facts to Data 57 JuRIMETRICS 169, 171-72, https://ssrn.com/abstract=2808044 [https://perma.cc/3 4Q4-46QT] [hereinafter Kaal, Disruptive Innovation] (explaining how the current regulatory rulemaking process, which emphasizes ex-post facts-based trial-and-error rulemaking, leads to suboptimal outcomes because the pattern of disruptive innovation doesn't provide the time needed for fact gathering); Wulf A. Kaal, Dynamic Regulation for Innovation, in PERSPECTIV ES IN LAW, BuSINESS AND INNOVATION (Mark Fenwick, Wulf A. Kaal, Toshiyuki Kono \& Erik P.M. Vermeulen eds., https://ssrn.com/abstract=2831040) [https://perma.cc/K7JQ-855F] [hereinafter Kaal, Dynamic Regulation] (arguing that dynamic regulatory processes can solve the problem of innovation developing faster applicable regulations, or the so-called "pacing problem").

137. See Kaal, Dynamic Regulation, supra note 136 at 17-20 (describing the use of 
information for ex-ante rulemaking, dynamic regulation lowers unforeseen contingencies in the rulemaking process while increasing regulatory certainty. Identifying forms of dynamic regulation for the private investment fund industry has the potential to overcome many of the identified policy challenges associated with Title IV. ${ }^{138}$

\section{Dodd-Frank Impact on Private Fund Performance}

As previously noted, an important question repeatedly raised by the private investment fund industry lobby pertains to the impact of Title IV on private investment fund performance and profitability. Attempts to rescind Title IV via the Investment Advisers Modernization Act of 2016 and announcements of the Trump Administration pertaining to a reduction of the regulatory burden in the Dodd-Frank Act illustrate the highly politically sensitive nature of Dodd-Frank Act registration and disclosure obligations for the private fund industry.

The author's 2015 paper exploits a natural quasi-experiment to isolate the effects that were uniquely due to Title IV: private fund investment advisers with AUM of more than $\$ 150$ million are required to register with the SEC and are subject to substantially increased public disclosure obligations. ${ }^{139}$ To analyze the effect of Title IV on the private fund industry, this author and two co-authors used five years of private fund advisers' performance data with over 7,000 reporting private funds in a regression discontinuity (RD) design, using multiple hand-selected control groups and several iterations of broad and narrow RD designs and robustness checks.

The findings in this paper are consistent and do not support the private fund industry's claims that the increased supervision and disclosure mandated in the Dodd-Frank Act have a negative effect on private fund earnings. Using an array of robustness tests validating the RD results, the paper shows that the requirements introduced by the Dodd-Frank Act create no significant effect on private fund performance. The P-values for all RD results are above the 5\% level and confirm the finding of no affect. By contrast, the private fund industry expected the introduction of the DoddFrank Act to result in negative effects on private investment fund returns. The absence of any statistically significant effect of mandatory disclosure on

various types of feedback effects in dynamic regulation).

138. Cf. id. at 20-21 (positing that deferred-prosecution-agreements and venture capital investments demonstrate where innovation is trending such that they can be used as feedback processes within dynamic regulation).

139. See Kaal, Luppi, \& Paterlini, supra note 9 (describing a study that is attempting to quantify the impact of the Dodd-Frank Act disclosure requirements on private fund performance). 
hedge fund returns may suggest that the transparency costs associated with disclosure do not significantly affect the profitability of hedge fund advisers.

\section{B. Systemic Risk}

The public media, politicians, and regulators regularly debate the potential for private investment funds to contribute to systemic risk in financial markets. Because the private investment fund industry experienced substantial growth over the past two decades, concerns about hedge funds' systemic risk have increased, and regulators have taken measures to mitigate the possible risks associated with these funds. The Dodd-Frank Act created the Financial Stability Oversight Council ("FSOC") with the primary mandate of guarding against systemic risk and correcting perceived regulatory weaknesses that may have contributed to the financial crisis of 2008-09. The SEC collects data pertaining to private fund advisers in order to facilitate the FSOC's assessment of non-bank financial institutions' potential systemic risks.

In a first paper on private investment funds' systemic risk implications, this author evaluated the Dodd-Frank Act's potential to address the systemic risk implications of private investment funds. ${ }^{140}$ The paper created and evaluated data evidence that demonstrated that the SEC's data collection encountered accuracy and consistency problems that hampered the FSOC's ability to evaluate the systemic risk of private funds. ${ }^{141}$ The author showed that while the SEC's data played a crucial role in all stages of FSOC's systemic risk assessment of private funds, the FSOC relied most heavily on some of the most problematic disclosure items collected by the SEC.

The paper demonstrated that the data collected via Form PF had several core shortcomings. These included: the ambiguity of several key questions on Form PF, the inaccuracy of Form PF definitions and the corresponding insufficiency of SEC guidance for Form PF, and difficulties in aggregating the required Form PF information. ${ }^{142}$

By referencing the author's prior work and using the data collected in surveys to analyze the systemic risk of private investment funds, ${ }^{143}$ the paper

140. See Kaal, Systemic Risk, supra note Error! Bookmark not defined., at 167-69 (detailing how the Dodd-Frank Act empowered the SEC to promulgate rules intended to mitigate the private fund industry's potential systemic risk, and how, despite challenges, the SEC's chosen method, collection of data through Form PF, has been accepted by the industry).

141. See id. at 190-93 (sharing the results of the analysis, demonstrating Form PF data insufficiency and possible inaccuracy).

142. See id. at 191 (citing his own prior work to demonstrate shortcomings of Form PF).

143. See Kaal, Systemic Risk, supra note Error! Bookmark not defined., at 168 (citing two essays as indicating that the mandated data collection in Form PF could cause difficulties for FSOC in evaluating the systemic risk of hedge funds); Registration, supra note 9; Kaal, 
demonstrated that the systemic risk assessment process employed by the FSOC was suboptimal. ${ }^{144}$ Several core Form PF questions that provide specific information for FSOC's stage one threshold assessment encounter problems. More specifically, the definition of RAUM required substantive interpretation by filers. FSOC used valuations in Form PF that are associated with RAUM, such as gross asset value of reporting fund (Question 8), the value of derivative positions (Questions 13 and 44), financing information and financing liquidity (Questions 46 and 58), as well as gross and net assets value of reporting fund (Questions 8 and 9) to determine various stage one thresholds. Given FSOC's direct or indirect use of RAUM-related data (and FSOC's emphasis on such data), in combination with the author's prior study suggesting that RAUM requires substantial interpretation, the paper showed that it was at least questionable if FSOC would be able to use the related Form PF data effectively and sustainably for its systemic risk evaluations and the designation of non-bank financial companies as systemically risky. ${ }^{145}$

The paper further showed that in addition to the specific matching of Form PF data issues with FSOC's uses of Form PF data, Form PF data may also have presented several more generic areas of concern for FSOC's systemic risk evaluation. ${ }^{146}$ Over $40 \%$ of respondents in the author's prior study suggested that they disagreed with definitions or instructions in Form PF. ${ }^{147}$ This suggested that a large proportion of filers are uncertain as to how Form PF questions are to be answered. This uncertainty raised the possibility that the filers were using estimates and a variety of assumptions to complete Form PF. ${ }^{148}$ If FSOC relied on Form PF data in its systemic risk assessment that is subject to inaccuracies, the paper suggested that that FSOC's work pertaining to private funds could in turn be subject to errors. ${ }^{149}$

In a second paper on private investment funds' possible systemic risk, the author showed that private investment fund advisers' systemic risk disclosure obligations under Title IV of the Dodd-Frank Act and SEC implementation rules had unanticipated knock-on effects on other areas of the law and hedge fund practices. More specifically, Federal Bankruptcy Rule 2019 (Rule 2019) had been the subject of intense professional and scholarly debate before the enactment of the Dodd-Frank Act. ${ }^{150}$ The federal

Private Fund Disclosures, supra note 9.

144. See Kaal, Systemic Risk, supra note 10, at 190-193 (discussing the sub-optimality of systemic risk data).

145. See id. at 192-93.

146. See id. at 193.

147. See Kaal, Private Fund Disclosures, supra note 9, at 26 (indicating that $40.82 \%$ of respondents disagreed with definitions or instructions in Form PF).

148. See Kaal, Systemic Risk, supra note Error! Bookmark not defined., at 193.

149. See id. at 193.

150. See Kaal, Bankruptcy, supra note 9, at 195. 
bankruptcy bench, practitioners, and academics debated the importance of the purported purpose of Rule 2019, the necessity for hedge funds to protect trading strategies and proprietary information, and the role of creditors and groups of creditors in the bankruptcy process. This paper added another element to the debate by evaluating possible implications of systemic risk disclosures by hedge fund managers under Title IV of the Dodd-Frank Act and SEC implementation rules in the bankruptcy context. In the paper, the author provided evidence of a substantial overlap between systemic risk disclosure requirements under Title IV and the disclosure requirements under the fully-revised version of Bankruptcy Rule 2019 (Revised Rule 2019). ${ }^{151}$

The paper demonstrated that public access to systemic risk disclosures by hedge fund managers under the Dodd-Frank Act and SEC implementation rules could improve hedge funds' distressed investments and their bankruptcy practices. ${ }^{152}$ Systemic risk disclosures could play a possible role in bankruptcy especially if more evidence emerges suggesting that Revised Rule 2019 could result in less overall disclosure by distressed debt investors. The mere threat of public access or sharing of hedge funds' systemic risk data filings in Form PF filings between the SEC and the federal bankruptcy bench could help facilitate some level of discipline for distressed debt investors' engagements in the bankruptcy process. ${ }^{153}$ The commonalities between disclosure requirements under the Dodd-Frank Act and Revised Rule 2019 suggested a possible role for systemic risk disclosures in the bankruptcy process.

The paper highlighted that the threat of public disclosure of systemic risk filings by hedge funds via the bankruptcy process only marginally affected hedge funds' tactics and their role in distressed investing. ${ }^{154}$ Hedge funds' disclosure obligations under the Dodd-Frank Act were then still rather generic. The SEC had not yet standardized the requirements, and it was unclear if the SEC would expand the systemic risk disclosure obligations for hedge funds investing in distressed securities. The paper asserted that the hedge fund industry's continuous, expanding, and increasingly assertive presence in distressed securities investments could change this evaluation in the future. ${ }^{155}$

In a third paper, published five years after the enactment of the DoddFrank Act, this author summarized the pre- and post-crisis debate and

151. See id. at 195.

152. See id. at 232.

153. See id. at 200-01, 226, 232-33.

154. See id. at 201, 232.

155. See id. at 225 (predicting that some of the discussed risk disclosures may become more relevant for the bankruptcy process going forward). 
highlighted and contrasted the post-crisis evidence regarding hedge funds' alleged systemic risk. ${ }^{156}$ In particular, the author examined evidence regarding specific factors surrounding hedge funds' possible contributions to systemic risk, including risk management incentives, leverage, liquidity characteristics, regulation, financial stability, transparency, and their potential to induce and perpetuate market contagion. ${ }^{157}$

The paper outlined the empirical evidence on hedge funds' possible systemic risk in the aftermath of the 2007-08 financial crisis. ${ }^{158}$ Several theoretical academic studies pointed to the potential for a possible link between hedge funds and systemic risk, especially as it relates to liquidity. Another strand of literature examined in the paper evaluated the potential for "tail risk" induced by hedge funds' risk management incentives that may increase risk-taking and leverage while shrinking hedge fund liquidity. ${ }^{159}$ The paper evaluated academic studies examining several additional factors in this process, including hedge funds' exposures to macroeconomic risks, their contribution to a "shadow banking" system, and the potential for hedge funds to induce and perpetuate market contagion.

\section{Private Fund Investor Due Diligence}

Since 2010, investment due diligence has become an increasingly litigated issue in the capital formation and allocation process. ${ }^{160}$ Lock step with the growth of the private investment fund industry, private fund investor due diligence litigation has increased significantly since the financial crisis of 2008-09. Courts in the early 2010s started to set out private fund investor due diligence standards and provided guidance on the requirements and limits of due diligence. The increasing due diligence litigation record underscores the heightened importance of due diligence in the capital formation and allocation process since the financial crisis of 2008-09.

Despite the increasing relevance of investment due diligence in the capital formation and allocation process and despite increasing litigation in the context of investment due diligence, the industry is mostly left to its own devices to ensure adequate due diligence standards apply. Little to no

156. See Kaal \& Krause, supra note Error! Bookmark not defined., at 3-21 (outlining the debate regarding the potential for hedge funds to contribute to systemic risk in financial markets and examining evidence about specific factors surrounding hedge funds' possible contributions to systemic risk).

157. See id. at 1.

158. See id. at 12-19 (summarizing empirical evidence gathered by several scholars before concluding that hedge funds may play a role in introducing at least some systemic risk into the financial system).

159. See id. at 20.

160. See Kaal, Due Diligence, supra note Error! Bookmark not defined. at 8. 
guidance existed prior to the author's study on applicable standards for private investment fund due diligence. Available resources describe best practices but do not sufficiently outline the legal requirements pertaining to private investment fund due diligence. The available case law only marginally provides relevant guidance on private fund investor due diligence.

The author's study provided the first comprehensive evaluation of the changing private fund investor due diligence landscape. ${ }^{161}$ To provide the industry with data, data trend analyses, and guidance on applicable legal private fund investor due diligence standards, the author examined two datasets: (1) private investment fund advisers' SEC Form ADV II filings from 2007 to 2014 ( $\mathrm{N}=100392$ ), and (2) the publicly available litigation record pertaining to private fund investor due diligence from 1995 to 2015 $(\mathrm{N}=572)$. After highlighting important changes in the quality and quantity of private fund investor due diligence disclosures in SEC Form ADV Part II, the author summarized and illustrated the entire litigation record on private investment fund due diligence from 1995 to 2015, breaking down individual expert testimony provided by due diligence experts in courts and evaluating expert guidance on applicable investor due diligence best practices. ${ }^{162}$

To summarize the results, the data provided in the author's study suggested that since 2010 private fund advisers increasingly engaged in private fund investor due diligence, partially in an effort to protect themselves from investor criticism and lawsuits. ${ }^{163}$ Since 2010, an increasing number of SEC Form ADV II brochure filers included investor due diligence disclosures, and the number of filers who included those disclosures remained relatively even between 2012 and 2014. The quantity of investor due diligence disclosures relative to total SEC Form ADV II brochure filings had increased substantially; the due diligence count exceeded the total ADV II filings for the first time in 2014. Filers appeared to see a need to increase the quantity of investor due diligence disclosures in Form ADV II between 2011 and 2014. The increasing caseload on private fund investor due diligence since 2005 could have suggested that applicable legal standards needed to be further clarified. ${ }^{164}$

The data used in the study demonstrated that between 1995 and 2015 private fund investor due diligence had reached new and lasting prominence in the court system. ${ }^{165}$ Madoff-related cases in the aftermath of the discovery of the Madoff Ponzi scheme in 2008 only partially explained the significant

161. See id. at 9 .

162. See id. at 9-10.

163. Id. at 10, 24, 59 .

164. Id. at 11 .

165. Id. 
increase in the prevalence and importance of private fund investor due diligence after 2009. The study demonstrated that the legal standards applicable to private fund investor due diligence were somewhat inconsistent and suboptimal and merited clarification.

In the study, the author predicted that the heightened emphasis on private fund investor due diligence as demonstrated in the study foreshadowed the possibility of standardization of private fund investor due diligence. ${ }^{166}$ Lack of standards for private fund investor due diligence could partially be attributed to private funds' unique position in markets - unlike mutual funds, private funds evolved as unregistered entities, free from most regulatory oversight. Accordingly, private fund investor due diligence evolved without regulatory oversight. The study suggested that private investment fund due diligence may follow the same evolution as banks' risk evaluation. Whereas in the early 2000s banks operated with general risk evaluation strategies but no uniformity and no applicable standards, today banks' risk evaluation is heavily regulated and turned into a science.

\section{CONFLUENCE OF PRIVATE AND Mutual FundS}

Increasing evidence suggests that the traditional distinction between mutual and private funds is dissipating. Prior to the 2008-09 credit crisis, the asset management industry was bifurcated into two distinct product segments, regulated (mutual) funds and private funds. That traditional distinction between mutual and private funds is dissipating. The author's contributions in this context ${ }^{167}$ conceptualized the confluence between mutual funds and private investment funds as a process and identified a trend that alternative mutual funds and other products that are fundamentally mutual funds are increasingly becoming more like hedge funds. ${ }^{168}$ The articles show that changes pertaining to hedge funds in the regulatory framework post Dodd-Frank Act tend to render hedge funds and hedge-fundlike vehicles more mutual-fund-like. This is not just a result of more stringent regulations enacted via the Dodd-Frank Act in the aftermath of the financial crisis; the liberalization of the advertising restrictions post DoddFrank Act also makes hedge funds more like mutual funds.

Several factors suggest that mutual funds are becoming more like hedge

166. Id. at 60 .

167. Kaal, Confluence, supra note Error! Bookmark not defined.; Kaal \& Anderson, supra note Error! Bookmark not defined..

168. See generally Kaal, Confluence, supra note Error! Bookmark not defined. (examining factors affecting the confluence of mutual funds and hedge funds and its consequences); Kaal \& Anderson, supra note Error! Bookmark not defined. (examining the investment strategies and risk attributes that mutual funds and hedge funds share). 
funds as a matter of investment strategy, while hedge funds are becoming more like mutual funds as a matter of the regulatory framework. ${ }^{169}$ The factors that perhaps best illustrate the confluence of private and mutual funds include the growth of the private fund industry and the proliferation of retail alternative funds in combination with the fundamental reshaping of the regulatory landscape for the private fund industry. ${ }^{170}$ Market-driven factors contributing to this confluence include the emergence and proliferation of so-called retail alternative or hybrid funds, such as synthetic hedge funds and unconstrained mutual funds. Other important confluence factors include the increasing side-by-side management of mutual funds and hedge funds, and public offerings of alternative asset managers, among others, in combination with the fundamental reshaping of the regulatory landscape for the hedge fund industry through the Dodd-Frank Act and the JOBS Act. ${ }^{171}$

Since the early 2010's, both private and regulated fund managers have been offering "liquid" alternative products to the same investor segments. Liquid alternatives offer adequate management fees and strong growth potential for mutual fund managers. For private managers, liquid alternative products provide access to large asset pools, including defined contribution plans, which were otherwise unavailable to private fund advisers. Increased offerings of liquid alternatives are managers' response to investor demands for a combination of risk mitigation, liquidity, the lower fees associated with mutual funds, and the absolute returns of private funds. Investments in liquid alternatives have more than doubled since 2008 and represent over $\$ 550$ billion in assets. ${ }^{172}$

Retail investors' preferences are a major factor in the confluence of private and mutual funds. Retail investors gained access to private fund strategies and higher returns through liquid alternative funds. In fact, the overall demand in the alternative investment sector is largely driven by retail investors who seek not only the prospect of significant performance but also risk-adjusted and consistent returns that are not correlated to the market. ${ }^{173}$

169. Id.

170. Id. at 1 .

171. Id. at 3 .

172. SEI, The Retail Alternatives Phenomenon: What Enterprising Private Fund MANAGERS NEED TO KNOW 2 (2013), http://goo.gl/orKIKD [https://perma.cc/6LH8-CQNC].

173. See McKinsey \& COMPANy, The Trillion-Dollar Convergence: CAPTURING the NeXt Wave of Growth IN Alternative Investments, 3 (2014) ("Retail investors, meanwhile, are moving rapidly into the market, as new product vehicles provide unprecedented access to a broad range of alternatives managers and strategies. Structural, rather than cyclical, forces are accelerating the adoption of alternatives, chief among them the linking of alternatives to critical investment outcomes - a phenomenon that takes the value of alternatives strategies 'beyond alpha.' Gone are the days when the sole attraction of alternatives was the prospect of high-octane performance. The market meltdown caused by the global financial crisis, coupled with the extended period of volatility and macroeconomic 
Through liquid alternatives retail investors were able to merely pay mutual fund fees, which in turn increased demand by retail investors for liquid alternatives. $^{174}$

\section{A. Evidence}

The emergence and proliferation of unconstrained mutual funds ("UMFs") provides important evidence illustrating the phenomenon of confluence between mutual and private funds. ${ }^{175}$ UMFs display characteristics of both mutual funds and private funds, and they occupy a unique market niche. More specifically, by combining the regulatory structure of a mutual fund with the investment strategy employed by a private fund implementing a credit strategy and principally trading fixed income instruments, UMFs transcend several of the traditional investment and legal distinctions which have characterized mutual funds and private funds. ${ }^{176}$ UMFs are subject to the same regulatory framework as traditional mutual funds, and they are widely offered and available to retail investors who would otherwise be excluded from investments in private investment funds.

The author provides evidence that UMFs share multiple investment strategies and risk attributes with fixed income hedge funds. Analyzing trading data and prospectuses of a hand-selected sample of all unconstrained mutual funds launched from 2010 through 2015 ( $\mathrm{N}=449)$, the author provided an overview of the evolution of unconstrained mutual funds, contrasting core characteristics with publicly available data pertaining to benchmarked mutual fund investment indices. ${ }^{177}$

UMFs exceeded the typical mutual fund "engagements" in almost all quantifiable categories. The data analysis in the study demonstrated that UMF trading of the referenced security and contract types clearly exceeded the average "engagements" for mutual funds as a group. ${ }^{178}$ For instance, in terms of short selling, UMFs exceeded other funds by more than twenty percent in engagements. Similarly, in currency exchange transactions, UMFs exceeded other funds by almost $30 \%$, in restricted securities by over $40 \%$, and in interest rates futures by over $50 \%$. Investment categories where

\footnotetext{
uncertainty that followed, have left their marks, and investors are now turning to alternatives for consistent, risk-adjusted returns that are uncorrelated to the market. They are also increasingly looking to alternatives to deliver on other crucial outcomes like inflation protection and income generation."); id. at 15 ("[R]etail flows are expected to be three to four times those of institutional flows. Demand has been strongest in the U.S. market ....”).

174. Id.

175. Kaal \& Anderson, supra note Error! Bookmark not defined., at 8.

176. Id. at 5 .

177. Id.

178. Id. at 37 .
} 
UMFs exceeded other funds by around $20 \%$ include options on futures, options on stock indexes, options on debt securities, and options on equities. ${ }^{179}$

Moreover, UMFs consistently exceeded mutual funds in relation to almost all investment categories. In particular, UMFs exceeded other mutual fund "permissions" by around 10-20\% in short selling, currency exchange transactions, securities of foreign issuers, restricted securities, commodity futures, options on index futures, options on futures, stock index futures, interest rate futures, options on stock indexes, options on debt securities, and options on equities. ${ }^{180}$ UMFs also used a significantly higher proportion of short sales (as a percentage of their respective Net Asset Value (NAVs)) than other mutual funds. They also displayed a substantially higher turnover rate than other mutual funds trading fixed income instruments. In particular, UMF turnover on average exceeded the turnover for other fixed income mutual funds by over $150 \% .{ }^{181}$ Finally, UMF fees generally exceed those of other mutual funds. While the average fee charged by a UMF (1.40\%) exceeds the average fee charged by those mutual funds in the Morningstar "non-traditional category" $(1.25 \%)$ and the average fee charged by all credit mutual funds as a group (1.15\%), the fees charged by UMFs are only marginally higher than those charged by other mutual funds. ${ }^{182}$

\section{B. Implications}

The confluence of mutual and private funds has long-term implications for both the private and mutual fund industries. The confluence of mutual and hedge funds affects the evolution of the hedge fund industry, rendering it a more widely recognized industry that is part of mainstream of finance. ${ }^{183}$ Confluence factors also make governance alternatives and possible governance improvements available for the mutual fund industry. Other implications include a positive effect on the growth of the retail alternative fund market and possible support for the proposition that the public/private distinction in federal securities regulation may be dissipating. Moreover, the confluence of mutual and investment funds through the proliferation of UMFs calls into question the effectiveness of retail investor protections under the Investment Companies Act of $1940 .{ }^{184}$

179. Id.

180. Id. at 38 .

181. Id. at 41 .

182. Id. at 42-43.

183. Kaal, Confluence, supra note Error! Bookmark not defined., at 4.

184. See Kaal \& Anderson, supra note Error! Bookmark not defined., at 48-53 (discussing the policy implications of UMF proliferation and how it undercuts the effectiveness of Congress' Company Act). 
Factors associated with the confluence of mutual and hedge funds help the private investment fund industry transition from an industry operating at the fringes of finance to one recognized as part of mainstream finance. ${ }^{185}$ Private investment funds have been able to proliferate and increasingly attract investors due in part to the Federal Reserve's policies and resulting low interest rates in the early 2010s. Unprecedented changes in the rules and regulations pertaining to the private investment fund industry under Title IV of the Dodd-Frank Act and the JOBS Act allow increased oversight of the industry and contribute to the increasing recognition of the industry as a fully regulated asset class. ${ }^{186}$

The confluence of mutual and hedge funds can also influence mutual fund governance. Given the proliferation of that confluence, it is possible that other governance models for mutual funds emerge over time. The proliferation of multimanager series trusts, for example, established a hitherto nonexistent alternative governance model for mutual funds. Multimanager series trusts can support mutual fund governance. Unlike the board in a traditional mutual fund governance setting, the board in a multimanager series trust arrangement is largely independent of any advisers within the fund group. Thus, independent directors on the board are not subject to conflicts of interest that often exist in traditional mutual fund governance settings if directors are affiliated with the investment adviser. Apart from its involvement in approving each adviser in a group structure, the board in the trust setting also typically has no involvement in selecting the group's investment advisers, creating fewer incentives for the board to comport with advisers in contradiction of fiduciary obligations. Despite the open issues and possible shortcomings of the multimanager series trust model, the trust model governance structure for mutual funds appears to offer lasting substantive governance improvements for mutual funds. ${ }^{187}$

Factors of mutual and hedge fund confluence increase the demand for retail alternative funds. While the market-driven proliferation of retail alternative funds itself drives confluence, several additional nonmarket confluence factors support the growth of the market for alternative funds. For instance, several provisions in the Dodd-Frank Act revised legal requirements applicable to private investment funds that in effect assimilated the legal requirements of mutual and hedge funds. Merging the regulatory requirements applicable to mutual funds with the formerly more distinct rules applicable to private investment funds creates incentives for private investment managers to set up retail alternative funds. ${ }^{188}$ A higher supply of

185. Kaal, Confluence, supra note Error! Bookmark not defined., at 16.

186. Id.

187. Id. at 17.

188. Id. 
retail alternative funds, in turn, is likely to further increase investor demand for retail alternative funds. A higher demand for retail alternative funds, in turn, precipitates more sustainable market-driven confluence of the mutual and hedge fund industries. ${ }^{189}$

The mandatory investment adviser registration provisions under the Dodd-Frank Act incentivize investment advisers to set up retail alternative funds. Prior to the enactment of the Dodd-Frank Act, the registration of a hedge fund was a significant disincentive for investment managers to enter into the mutual fund sector. Investment advisers to hedge funds disfavored registration with the SEC because they considered the associated disclosures intrusive and feared negative effects on profitability. By eliminating previous registration exemptions and requiring investment advisers with AUM of more than $\$ 150$ million to register with the SEC, the Dodd-Frank Act mandates SEC registration and reporting of information that was hitherto considered proprietary and private. ${ }^{190}$ Hedge fund advisers who are required to register with the SEC have incentives to also manage mutual funds or set up retail alternative funds because the regulatory burden is minimally higher in comparison with preregistration legal requirements. ${ }^{191}$ Some registered hedge fund advisers may choose to offer hedge fund strategies in a mutual fund setting, thus increasing the trend towards confluence.

Mutual and private investment fund confluence contributes to the gradual erosion of the public/private distinction in federal securities regulation. Beyond the retail investor-protection concerns associated with UMFs, the growth in the number of UMFs calls into question the continuing relevance of the public/private divide in federal securities regulation. ${ }^{192}$ The academic literature on this topic has explored a number of different subjects and suggested a continuous blurring of the traditional boundary lines between regulated companies and activities on the one hand, and "private" firms and transactions on the other hand, including blurring that follows the enactment of new legislation (for instance, the JOBS Act and the Crowdfunding Act). The confluence of mutual funds and private funds is an important example of the blurring of the public / private distinction in federal securities regulation. ${ }^{193}$

Finally, the proliferation of unconstrained mutual funds calls into question the effectiveness of retail investor protections under the Investment Companies Act of 1940. The author's analysis reveals, among other things, that UMFs share several important investment strategy and risk attributes

189. Id.

190. Id. at 14 .

191. Id. at 18 .

192. Kaal \& Anderson, supra note Error! Bookmark not defined., at 51.

193. Id. at 52 . 
with private funds. These include broad authority to trade almost any type of security, including illiquid securities; take concentrated investment risks in individual securities, sectors, or markets; make extensive use of derivatives; engage in short selling; and change the duration of the portfolio without any effective limit. ${ }^{194}$ However, unlike private funds, which are generally limited to investors who satisfy particular investment sophistication and net worth requirements, shares of UMFs may be purchased by retail investors, including those with quite limited or even no investment experience.

\section{BLOCKCHAIN TECHNOLOGY APPLICATIONS FOR PRIVATE INVESTMENT FUNDS}

Starting in 2015, private investment fund managers have begun to embrace the use of blockchain technology to facilitate investment and process optimization. ${ }^{195}$ Several private investment funds have spearheaded the implementation of blockchain technology and smart contracting in their business model and continue to expand it. While some funds simply focus on trading bitcoin and other cryptocurrencies to avoid market fluctuations, others invest in and/or acquire companies that use blockchain technology to provide synergies to their other portfolio companies. Yet others go much further by fully automating a hedge fund secured by blockchain technology. This is accomplished by improving the administrative procedures of private equity deal making or using cryptocurrencies as incentives for data scientists' competitive models that facilitate investment analysis efficiencies.

Several key benefits are associated with the introduction of blockchain technology in private investment funds' back-office administrative processes and compliance. By automatically recording all transactions in a given private investment fund along with any documentation or information that is associated with a given transaction, blockchain technology reduces the otherwise significant costs associated with human oversight in recording, organizing, and maintain investment fund data and records. Blockchain technology also creates a verified marketplace and provides market participants with reliable and fully transparent data on market transactions. The technology reduces the need for information exchange among parties because all transactions are fully recorded and transparent. Blockchain increases security because transactions are recorded in an immutable

194. Id. at 9 .

195. Wulf A. Kaal, Blockchain Innovation for Private Investment Funds (U. of St. Thomas Minn., Legal Stud. Res. Paper No. 17-21, 2017), https://ssrn.com/abstract=2998033 [https://perma.cc/MX47-AA6S], at 3. 
database that ensures the validity of data and removes expensive security procedures and labor-intensive data maintenance while reducing the need for a paper trail. Overall, the technology allows for a significant simplification of transactions and enormous increases in efficiency and speed of private investment fund transactions while providing significant security improvements.

Diversification is a key element of blockchain-based change in the private investment fund industry. A benefit of investing in digital currencies rather than traditional investments is that digital currencies can be immune to the vicissitudes of traditional stock investments and the equity markets. Although crypto investments can be just as, or more, volatile than traditional investments, digital currencies might be used to hedge against traditional investments.

The use of blockchain technology increases the competitive pressure in the private investment fund industry. Private investment funds implementing blockchain technology are facilitating and spearheading radical changes in financial markets. First and foremost, the structural characteristic of blockchain as a decentralized model for financial transactions disintermediates and disrupts the existing financial infrastructure. Private investment funds that are first movers in the implementation of the blockchain infrastructure systems in finance directly contribute to that disintermediation and facilitate the accelerating evolution of the blockchain infrastructure in finance.

The competitive pressure in the private investment fund industry increases through operational and business efficiencies gained by those funds that implement the technology. Most large fund advisers in the private equity and hedge fund industry have not yet considered implementing blockchain technology in combination with big data applications and artificial intelligence. This, however, may change in the foreseeable future if and when larger managers realize that their smaller competitors who utilize these technologies gain substantial operational efficiencies and cost savings and are able to substantially diversify their portfolio holdings via such technologies. The threshold for change for bigger managers may be dictated by the implementation cost of such new technologies. If and when the longterm benefits of using the technologies exceed the implementation cost, which are much larger for larger managers than for the smaller managers who are currently experimenting with such technologies, larger managers are incentivized to start the innovation process as well.

The increasing use of blockchain technology in combination with artificial intelligence and big data contributes to the market pressure on the fee structure of private investment funds. Anecdotal evidence suggests that the majority of private fund advisers that use blockchain technology, 
artificial intelligence, and big data in different aspects of their operations or strategy have a substantially lower fee structure than those who do not use them. While the overall proportion of strategies of private investment funds that apply modern technologies, including blockchain technology, is still small, as the use of blockchain technology grows in the private investment fund industry, the pressure on the fee structure is likely to continue to grow.

Blockchain technology enables managers to charge per-transaction fees which undermines the existing $2 / 20$ fee model. Blockchain technology facilitates a seamless and efficient calculation of management fees per transaction. In contrast to the traditional settlement and calculation of fees in a per-transaction model that created a prohibitive amount of work making such operations very difficult to execute, blockchain technology overcomes all of these restrictions. It enables the fully automated allocation of the appropriate fee to the correct executed trade and associated client account without any manual reconciliation or settlement. While not all blockchainenabled private investment funds charge per-transaction fees, the majority of private fund advisers that use blockchain technology, artificial intelligence, and big data in different aspects of their operations or strategy charge their investors lower fees.

\section{CONCLUSION AND OUTLOOK}

This Article examined the author's scholarly contributions and empirical findings pertaining to private investment fund regulation from 1998 to 2016, tracing the main regulatory developments in each phase since 1998. Starting with a discussion of and the implications of LTCM and associated regulatory changes since 1998, the author's scholarly contributions in phase one focused on evaluating the proposed remedies for private fund investment regulation and suggesting alternatives. Evaluating the effects of regulatory changes in the aftermath of the Dodd-Frank Act, the author's scholarship in phase two summarized the regulatory evolution of the private fund industry and focused particularly on the evaluation of the effects of the Dodd-Frank Act on the private investment fund industry. Scholarship in phase two also analyzed the shifting evaluation of the possible systemic risk posed by the private fund industry and pertinent developments in private investment fund investor due diligence. The author's scholarship in phase three evaluated the implications of the emerging evidence of confluence of prior separate asset classes in the aftermath of the Dodd-Frank Act and other long-term implications of the regulatory overhaul under the Dodd-Frank-Act, such as the dilution of the public/private distinction in federal securities regulation.

Future scholarship on private investment fund regulation will likely 
continue the existing work in the context of the effects of the Dodd-Frank Act, and it will further the examination of evidence on confluence of the hitherto separate asset classes (mutual funds and private funds). In particular, comparative empirical scholarship on the different impact of the Alternative Investment Fund Managers Directive in Europe and Title IV of the Dodd-Frank Act could help clarify how and when private investment fund managers who invest internationally and use foreign branches are regulated and what impact such regulation across borders has on the industry. In the confluence context, future scholarship will help ascertain the impact of private and mutual fund confluence. Other areas of future scholarship may include the evolution and impact of private fund investor due diligence requirements.

The rise of blockchain technology and the prominent applications of blockchain technology in the private investment fund industry serve as prominent examples of the impending seismic shifts in the private investment fund industry. Blockchain initiatives have significant implications for innovation in the private investment fund industry. As the industry continues to evolve in the blockchain realm, more change is inevitable. Legacy infrastructure upgrades via blockchain technology may only be a first step towards crypto integration and evolution via the private investment fund industry. 